\title{
THE MARMARA SEA GATEWAY SINCE 16 KY BP: NON-CATASTROPHIC CAUSES OF PALEOCEANOGRAPHIC EVENTS IN THE BLACK SEA AT 8.4 AND 7.15 KY BP
}

\author{
Richard N. Hiscott, ${ }^{1}$ Ali E. Aksu, ${ }^{1}$ Peta J. Mudie, ${ }^{2}$ Michael A. Kaminski, ${ }^{3}$ \\ Teofilo Abrajano, ${ }^{4}$ Doğan Yaşar, ${ }^{5}$ and André Rochon ${ }^{6}$ \\ ${ }^{1}$ Department of Earth Sciences, Memorial University of Newfoundland, St.John's, NF, Canada \\ A1B $3 X 5$ \\ ${ }^{2}$ Geological Survey of Canada - Atlantic, Dartmouth, NS, Canada B2Y 4A2 \\ ${ }^{3}$ Research School of Geological and Geophysical Sciences, University College London, Gower \\ Street, London, UK WCIE 6BT \\ ${ }^{4}$ Department of Earth and Environmental Sciences, Rensselaer Polytechnic Institute, Troy, NY \\ 12180 \\ ${ }^{5}$ Institute of Marine Sciences and Technology (IMST), Dokuz Eylül University, 35340 Inciralt1, \\ Izmir, Turkey \\ ${ }^{6}$ Institut des Sciences de la Mer de Rimouski (ISMER), Université du Québec à Rimouski, \\ Rimouski, QC, Canada G5L 3A1
}

\begin{abstract}
:
The Late Quaternary history of connection of the Black Sea to the Eastern Mediterranean has been intensely debated. Ryan, Pitman and coworkers advocate two pulses of outflow from the Black Sea to the world ocean at $\sim 16-14.7$ ky BP and $\sim 11-10$ ky BP. From $\sim 14.7-11$ ky BP and from $\sim 10-8.4$ ky BP, they suggest that the level of the Black Sea fell to -100 m. At $8.4 \mathrm{ky}$ $\mathrm{BP}$, they further claim that a catastrophic flood occurred in a geological instant, refilling the Black Sea with saline waters from the Mediterranean. In contrast, we continue to gather evidence from seismic profiles and dated cores in the Marmara Sea which demonstrate conclusively that the proposed flood did not occur. Instead, the Black Sea has been at or above the Bosphorus sill depth and flowing into the world ocean unabated since $\sim 10.5 \mathrm{ky}$ BP. This conclusion is based on continuous Holocene water-column stratification (leading to sapropel deposition in the Marmara Sea and the Aegean Sea), proxy indicators of sea-surface salinity, and migration of endemic species across the Bosphorus in both directions whenever appropriate hydrographic conditions existed in the strait. The two pulses of outflow documented by Ryan, Pitman and coworkers find support in our data, and we have modified
\end{abstract}


our earlier interpretations so that these pulses now coincide with the development of mid-shelf deltas: $\Delta 2$ (16-14.7 ky BP) and $\Delta 1$ (10.5-9 ky BP) at the southern end of the Bosphorus Strait. However, continued Black Sea outflow after 9 ky BP prevented the northward advection of Mediterranean water and the entry of open-marine species into the Black Sea for more than 1000 years. Sufficient Mediterranean water to change the Sr-isotopic composition of slope and shelf water masses was not available until $\sim 8.4 \mathrm{ky}$ BP (along with the first arrival of many varieties of marine fauna and flora), whereas euryhaline molluscs did not successfully populate the Black Sea shelves until $7.15 \mathrm{ky} \mathrm{BP}$. Instead of relying on catastrophic events, we recognize a slow, progressive reconnection of the Black Sea to the world ocean, accompanied by significant time lags.

Keywords: $\quad$ Marmara Sea Gateway, Bosphorus Strait, Black Sea Flood Hypothesis, Outflow Hypothesis, climate change

\section{INTRODUCTION}

The "Marmara Sea Gateway" connects the Black Sea and Eastern Mediterranean (Figure 1A, B). The gateway consists of (1) a linked set of narrow straits with shallow bedrock sills (the Bosphorus Strait with a sill depth of $\sim-40 \mathrm{~m}$; and the Dardanelles Strait with a sill depth of $\sim-70 \mathrm{~m}$ ) and (2) the inland Marmara Sea. The Marmara Sea fills a rugged, tectonically active depression comprising three abyssal basins reaching depths of $>1200 \mathrm{~m}$ and separated by cross-basin ridges (Aksu et al. 2000).

The Marmara Sea Gateway provides an unparalleled natural laboratory in which to study the evolution of Quaternary climate in central and northern Europe. This is because the narrow straits regulate all communication between the Black Sea and the world ocean through the small Marmara Sea, which acts as a sediment trap, registering, like a sensitive tape recorder, paleoceanographic events and paleoenvironmental changes in the catchment area of the rivers that drain into the Black Sea. The volume of the Marmara Sea is only $0.65 \%$ of the volume of the Black Sea, so there is enormous amplification in the Marmara sediments of the effects of Quaternary water exchange between the Aegean and Black Seas. The geometry of this gateway is analogous to a vacuum line in a chemistry laboratory, with its series of control valves and condensation traps.

Today, the Black Sea is swollen by the discharge of major European rivers (the Danube, Don, Dnieper, Dniester, Southern Bug), resulting in the net export of $\sim 300 \mathrm{~km}^{3} / \mathrm{yr}$ of water through the gateway. This volume represents fifty times the cumulative annual discharge of the small rivers entering the Marmara Sea. Satellite altimetry shows that the surface of the Black Sea is $\sim 30$ $\mathrm{cm}$ above the level of the Marmara Sea, which, in turn, varies between 5 and 27 


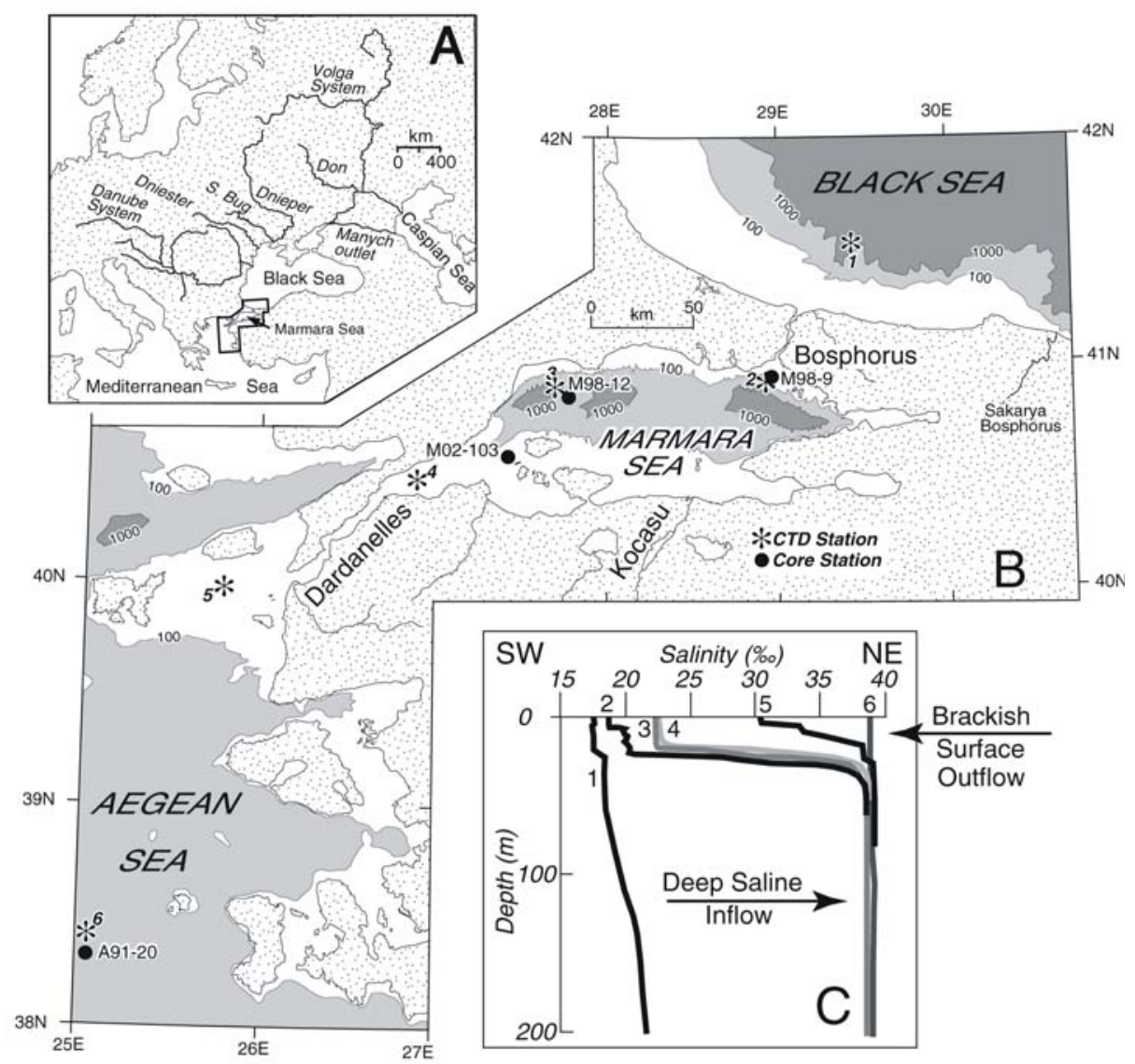

Figure 1. A: Location of the Marmara Sea and major European rivers entering the Black Sea. During deglaciation, the Volga system was connected to the Black Sea through the Manych outlet and a link to the Don River. B: Simplified bathymetry in meters (Aksu et al. 1999); location of cores M98-9, M98-12, M02-103 and A91-20; and location of conductivity-temperature-depth (CTD) stations 1-6, corresponding to data plotted in part C. The Sakarya Bosphorus no longer connects to the eastern end of the Marmara Sea because of Quaternary offsets along the North Anatolian Transform Fault. C: Salinity versus water depth in the upper $200 \mathrm{~m}$ (stations 1, 3, 6) or to the seabed (stations $2,4,5$ ), showing sharp salinity-controlled pycnocline at $~ 20-25$ m except in the Black Sea (subtle pycnocline at $130 \mathrm{~m}$ ) and the southern Aegean Sea (no low-salinity layer). The low-salinity surface lid originates from Black Sea outflow and promotes permanent stratification which in turn promotes sub-pycnocline oxygen depletion. Salinity (CTD) data from archives of Institute of Marine Sciences and Technology (IMST), Dokuz Eylül University, Izmir.

cm above the level of the northern Aegean Sea (Polat and Tuğrul 1996). These elevation differences drive the outflow across the gateway.

The present water exchange across the Bosphorus Strait is a two-layer flow. A cooler, lower salinity (17-20\%o) surface layer exits the Black Sea, while warmer, higher salinity (38-39\%) Mediterranean water flows northward through 


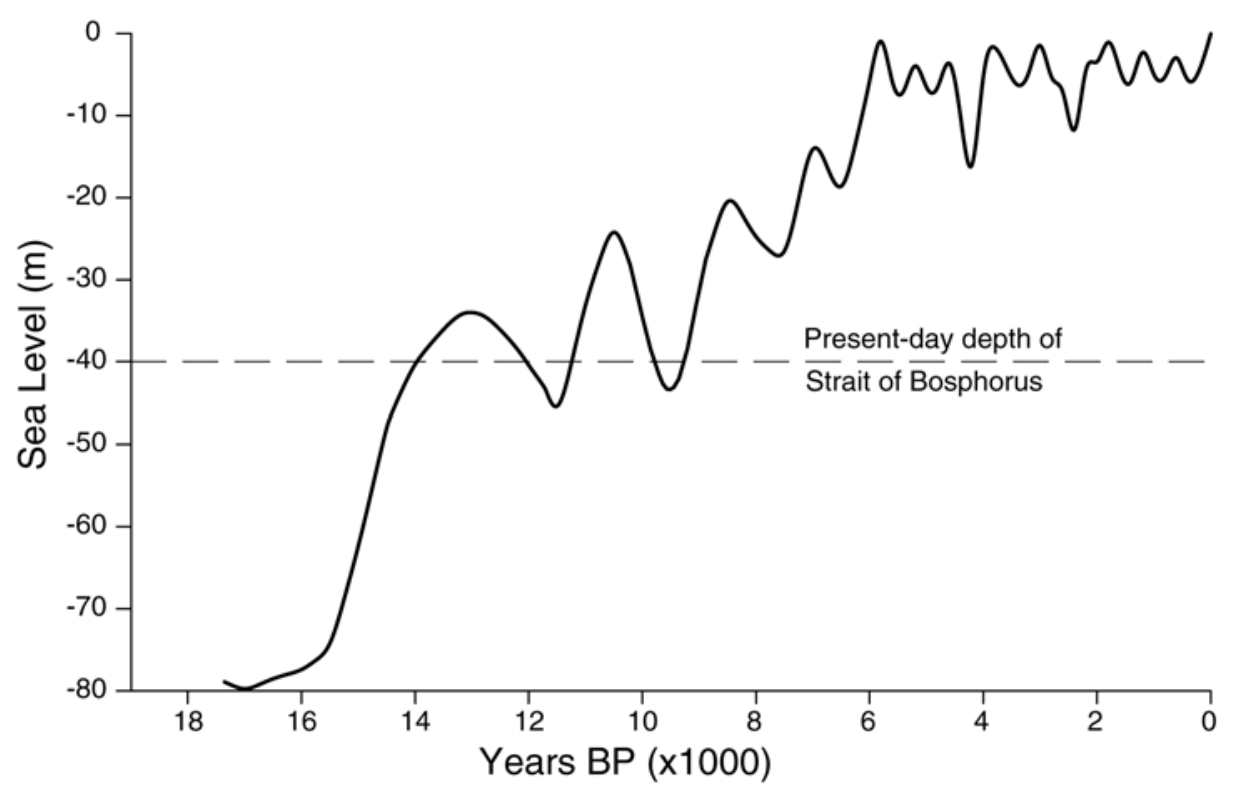

Figure 2. Record of Black Sea water levels compiled from radiocarbon dates on shells collected from former shorelines around the Black Sea coast and inner shelf (after Chepalyga 2002).

the strait at depth (Polat and Tuğrul 1996). The upper tens of meters of the water column in the gateway area (but not in the open Aegean Sea) are strikingly fresher than the deep water because of the Black Sea outflow (Figure 1C). The low-density surface layer prevents ventilation of the deeper water column, promotes organic-matter preservation, and fosters benthic communities adapted to suboxic to dysoxic conditions with $0.1-1.3 \mathrm{ml} / \mathrm{l}$ dissolved oxygen.

Throughout the Quaternary, the Black Sea experienced a complex series of transgressions and regressions (Figure 2) (Chepalyga 2002). Transgressions resulted from a combination of melting ice sheets and permafrost in Central Asia (east of the Ural Mountains), wet periods with increased rainfall, cooler time intervals with reduced evaporation across eastern Europe and west-central Asia, and periodic discharges of water from the Caspian Sea through the Manych Depression (e.g., the 16-14 ky BP late Khvalynean flood peak of Chepalyga, this volume). Whenever the sill in the Bosphorus Strait (or Sakarya Bosphorus as in Figure 1B) was subaerially exposed because of low global sea level (glacial stages 6, 4-2; see Yaltırak et al. 2002), the Black Sea oscillated independently, whereas at other times like today (interglacial stages), the level of the Black Sea was effectively pinned to the level of the global ocean because of free exchange across the Marmara Sea Gateway. Throughout its Quaternary history, the salinity of the Black Sea has varied from marine to semi-fresh. Salinity estimates used here follow the terminology of Chepalyga (1984): marine 
(30-40\% salinity), semi-marine (12-30\%o), brackish (5-12\%o), semi-fresh $(0.5-5 \%)$, and fresh $(<0.5 \%)$.

\section{RIVAL HYPOTHESES}

The means by which the Black and Mediterranean Seas were reconnected after the last glaciation is intensely debated. Ryan et al. (1997) and Ryan and Pitman (1998), modified by Ryan et al. (2003), proposed their Flood Hypothesis, which entailed a catastrophic refilling of the Black Sea basin by marine water at $\sim 8.4 \mathrm{ky} \mathrm{BP}$, an event they estimate to have taken place in less than two years. They link this controversial deluge with the biblical account of Noah's Flood and explain a low Black Sea (Neoeuxinian Lake) persisting well into the Holocene by advocating a dry central European climate. Before this flood, Ryan and coworkers argue for the scenario diagrammed in Figure 3A:

(1) a 16-14.7 ky BP meltwater-induced outflow from the Black Sea through the Bosphorus channel (= late Khvalynean flood peak of Chepalyga, this volume),

(2) an evaporative drawdown of the Black Sea to an elevation of -105 m from 14.7-12 ky BP,

(3) a 11.5-11 ky BP Black Sea transgression to -25 to $-30 \mathrm{~m}$ that caused a second outflow into the Marmara Sea from 11-10 ky BP, and

(4) a 10-8.4 ky BP evaporative drawdown of the Black Sea until it reached $\sim$-95 $\mathrm{m}$.

Because the Mediterranean and Marmara water levels had by $~ 8.4$ ky BP already risen to $\sim-25 \mathrm{~m}$, well above the present sill depth of the Bosphorus Strait, Ryan et al. (1997) hypothesized the existence of a sediment dam to hold back the global ocean. They concluded that the Marmara and Mediterranean catastrophically flooded into the depressed Black Sea basin when this hypothetical sediment dam in the Bosphorus channel was scoured away.

Initially, Ryan et al. (1997) relied on radiocarbon dates of the first euryhaline molluscs to populate the drowned shelves of the northern Black Sea as a marker for the time of flooding; these dates clustered at $\sim 7.15 \mathrm{ky} \mathrm{BP}$. Euryhaline molluscs require semi-marine to marine salinity of 20-40\% (Knox 1986), conditions only marginally attained in the Black Sea today (Figure 1C). Subsequently, Major (2002) and Ryan et al. (2003) shifted the date for flooding to $\sim 8.4$ ky BP based mainly on Sr-isotopic data, and they reinterpreted the $\sim 7.15$ ky BP shell ages as having resulted from an approximately 1300-year salinization time lag, after which the Black Sea shelf waters attained a salinity level appropriate for colonization by euryhaline fauna well after the actual reconnection took place. 


\section{A. Flood Hypothesis}

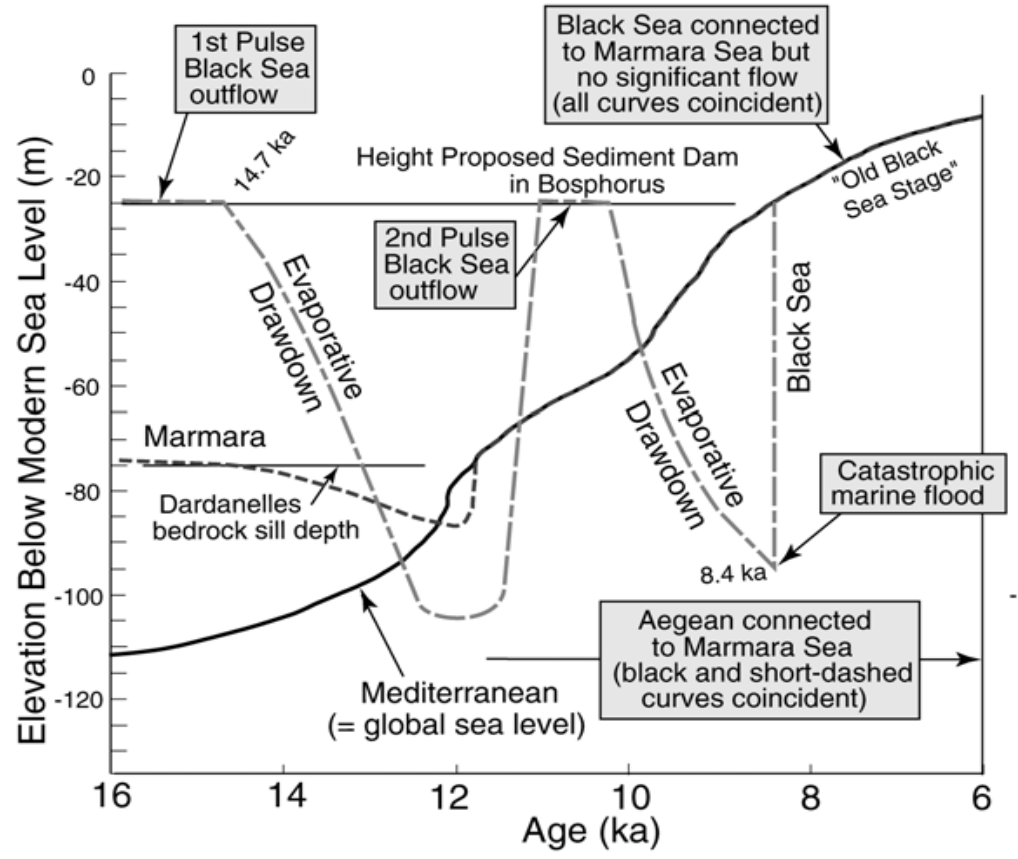

\section{B. Outflow Hypothesis}

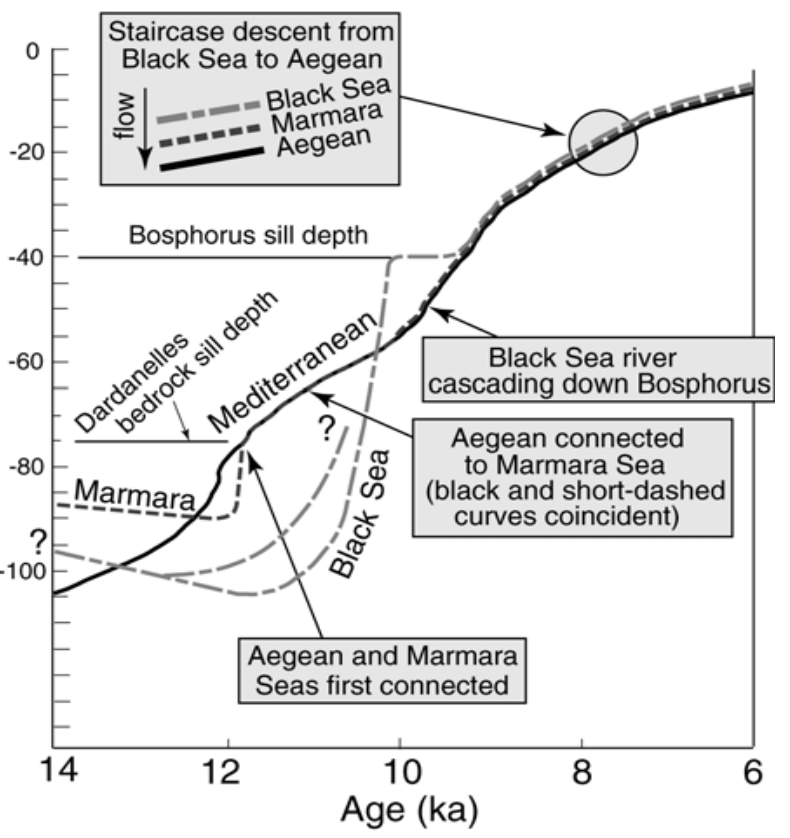

Figure 3. Schematic water-level histories of the Black, Marmara, and Mediterranean (Aegean) Seas according to A. the Flood Hypothesis of Ryan et al. (2003) and B. the original Outflow Hypothesis of Aksu et al. (2002a) and Hiscott et al. (2002). In both plots, the Mediterranean curve (solid dark line) is the Barbados (global) curve of Fairbanks (1989). When Mediterranean and Marmara curves (dotted dark line) are superimposed (e.g., from 12-10 ky BP in both plots), the Marmara Sea was an embayment of the Mediterranean. 
The flood hypothesis was initially challenged by several authors. Shifting the flood date from 7.15 to $~ 8.4$ ky BP satisfied the objections of Görür et al. (2001), but an extensive Russian literature on regional water-level variations still concludes that the Black Sea reached a level of $\sim-30 \mathrm{~m}$ by $\sim 10-9$ ky BP and has never been lower since (Figure 2). In the Marmara and Aegean Seas, sensitive proxy indicators in sediment cores have been interpreted by Aksu et al. (1995, 2002a, b, c), Çağatay et al. (2000), Kaminski et al. (2002), and Abrajano et al. (2002) as evidence that the Black Sea has been continuously exporting low-salinity water through the Marmara Sea Gateway since $10 \mathrm{ky} \mathrm{BP,}$ or perhaps earlier. This is the basis for our Outflow Hypothesis (Figure 3B). Physical sedimentological evidence from bedform asymmetry and deltaic progradation at the southern end of the Bosphorus Strait supports this interpretation (Aksu et al. 1999; Aksu et al. 2002a; Hiscott et al. 2002). These last authors named the youngest delta ( 10-9 ky BP) at the strait exit "delta 1," or $\Delta 1$.

We began to study the gateway area in 1995 and have acquired approximately 8500 line-km of airgun, sparker, and Huntec boomer profiles (vertical resolution $\sim 10-20 \mathrm{~cm}$ ), about 126 gravity and piston cores, and 78 radiocarbon dates from cores. A case has been built for continuous Black Sea outflow since $\sim 10 \mathrm{ky}$ BP that is rooted mainly in our large dataset from the Marmara and Aegean Seas, and less so from the Black Sea itself. Ryan et al. (2003) criticize our efforts to deduce the behavior of the Black Sea largely from adjacent waterways, but the unique configuration of the Marmara Sea Gateway perhaps makes it a better place to monitor the reconnection history than within the Black Sea itself. As an analogy, if one wants to know the number of spectators in a stadium, a count at the exit as people enter or leave is more reliable than an attempt to estimate the number of spectators from within the stadium. Our evidence from the connecting link between the Aegean and Black Seas leaves little doubt that the last phase of Black Sea outflow began as early as 11-10 ky BP and has continued to the present.

Ryan et al. (1997) and Ryan and Pitman (1998) instead proposed that the Black Sea was in a protracted phase of evaporative drawndown from 14.5-7.15 ky BP, ending with a catastrophic flood when the rising Mediterranean and Marmara Seas breached the sediment dam in the Bosphorus Strait. In their present version of events, Major (2002) and Ryan et al. (2003) acknowledge outflow at 11-10 ky BP but insist that it then stopped, first because evaporation lowered the level of the Black Sea and terminated the earlier connection during the interval 10-8.4 ky BP, and subsequently because the Black Sea remained sufficiently evaporative that it continued to receive net inflow from the Aegean Sea through the Bosphorus Strait. They suggest that this latter situation continued until $\sim 3$ ky BP, when the Black Sea's tributary rivers eventually attained near-modern discharges and the climate shifted to modern humidity and 


\section{Outflow Hypothesis II}

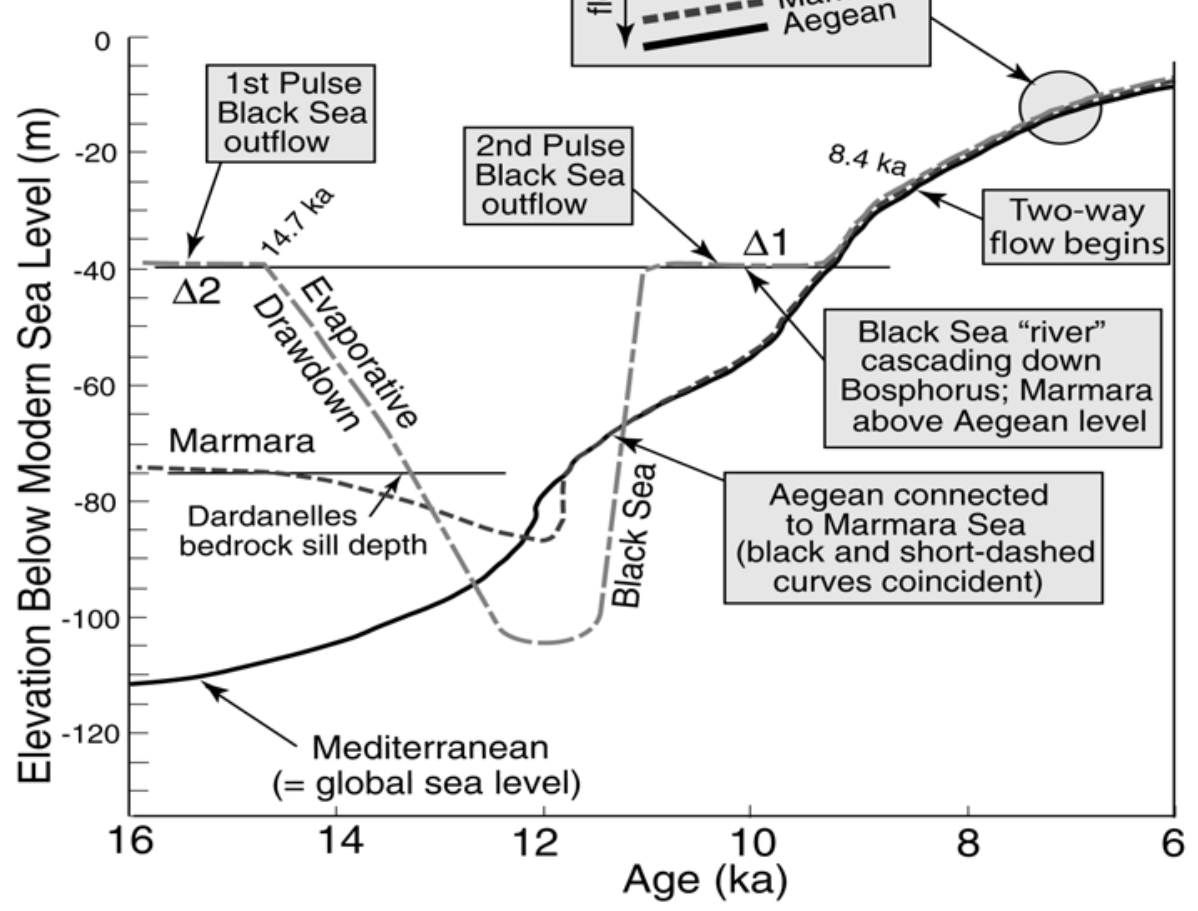

Figure 4. Modified Outflow Hypothesis, designated as version II. An 16-14.7 ky BP episode of Black Sea outflow is incorporated, and the second pulse of Black Sea outflow is initiated somewhat earlier than in Figure 3B.

rainfall levels. Only since $\sim 3$ ky BP (not shown in the plot of Figure $3 \mathrm{~A}$ ), in what is known as the New Black Sea stage, do Ryan et al. (2003) believe that water exchange between the Black Sea and the Mediterranean has been like that of the present, with significant Black Sea outflow across the gateway.

In the Marmara Sea, the Flood Hypothesis predicts thorough mixing of the water column between $\sim 10$ and $8.4 \mathrm{ky} \mathrm{BP}$, with a final turbulent stirring and flushing in of Mediterranean fauna and flora over a short period at 8.4 ky BP. According to the original Outflow Hypothesis, the Black Sea reached the $-40 \mathrm{~m}$ bedrock sill depth in the Bosphorus Strait first, initiating a cascade downslope into the rising Marmara Sea from $\sim 10-9$ ky BP and building delta $\Delta 1$ (Figure 5). This hypothesis does not involve a catastrophic flood but instead predicts stratification and low oxygen conditions in the Marmara Sea since 10 ky BP, similar to today (Figure 1C).

Is there any common ground between the Flood Hypothesis and our 
Outflow Hypothesis? Yes, but only for the period before 10 ky BP. For example, we see considerable merit in the proposal of Ryan et al. (2003) that there were two outflow events at $\sim 16-14.7$ and $~ 11-10$ ky BP, and we have incorporated these into a modified Outflow Hypothesis (version II, Figure 4). This modification does not violate any of the data presented by Aksu et al. (2002b) and Hiscott et al. (2002) and provides an explanation for the double unconformity present locally on the southwestern Black Sea shelf ( $\alpha$ and $\alpha 1$ of Aksu et al. 2002b). Also, the $16-14.7$ ky BP outflow event provides an attractive explanation for the older delta $2(\Delta 2)$ described by Hiscott et al. (2002) at the southern exit of the Bosphorus (Figure 5). With new cores, we have now established that the widespread mud drape on top of $\Delta 2$ and below the $\beta 3$ unconformity was forming at 10,950 yr BP based upon radiocarbon dating from Core M02-111 (Table 1, Figures 6 and 7B). A comprehensive reanalysis of the development of $\Delta 2$ and the younger $\Delta 1$, and the constraints they place on Black Sea outflow, is presented in a later section.

In this paper, we marshal previously published and new evidence from the Marmara and Aegean Seas to evaluate the history of connection between the Black Sea and the open ocean. The critical debating points between Ryan and coworkers and our research team can be reduced to two fundamental issues:

(1) Is there any evidence in the Marmara Sea Gateway that the strong Black Sea outflow that began at 11-10 ky BP was reduced to nothing ( 10-8.4 ky BP) and then very little (8.4-3 ky BP) as Ryan et al. (2003) have proposed?

(2) Is there credible evidence that early Holocene climate throughout the region was sufficiently arid to promote net evaporation from the Black Sea surface from $~ 10-3 \mathrm{ky} \mathrm{BP}$ ?

We first review the basis for the agreed early strong outflow (before $~ 10$ ky BP). Then, we evaluate whether environmental and paleoceanographic proxy data from younger deposits are compatible with a continuation of this outflow to the present day, or instead suggest a predominant Mediterranean influence across the Marmara Sea Gateway from 8.4-3 ky BP with significant net Black Sea outflow resuming only after that time.

\subsection{The 16-9 ky BP History of Connection and Black Sea Outflow}

Until 12 ky BP, global sea level was lower than the spill depth of the Marmara Sea at the Dardanelles Strait (e.g., Fairbanks 1989), effectively limiting water level in the Marmara Sea to a maximum height of $\sim-70 \mathrm{~m}$. Ryan et al. (2003) describe highstand deposits from the Black Sea dating to 16-14.7 ky BP that indicate overspill into the Marmara Sea at that time. This influx of water into the small Marmara basin (with $<1 \%$ of the volume of the Black Sea) would 


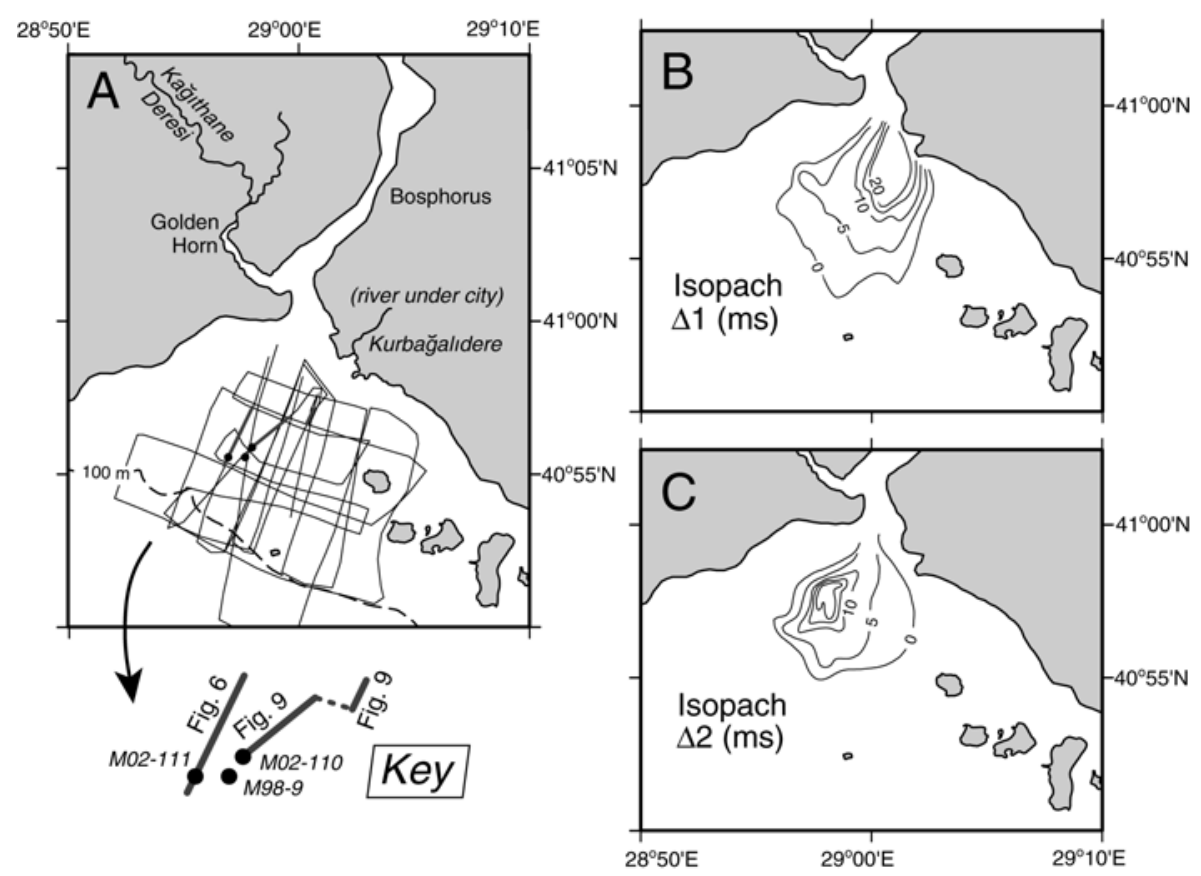

Figure 5. Maps of the area south of the Bosphorus Strait.

A. Boomer survey tracks ( 280 line-km), core locations, and key to the locations of seismic profiles shown in other figures (see enlarged labels for cores and seismic profiles below the map). The Kağıthane Deresi and Kurbağalı Dere are small rivers described in the text and Table 1.

B. and $\mathbf{C}$. Isopach maps of strait-mouth deltas, the younger $\Delta 1$ and the older $\Delta 2$, with sediment thicknesses in milliseconds of two-way travel time (10 $\mathrm{ms} \approx 7.5 \mathrm{~m})$.

have maintained its water level at the Dardanelles spill depth until 14.7 ky BP, creating a staircase descent from the Black Sea at $\sim-40 \mathrm{~m}$ (Figure 4) or $\sim-25 \mathrm{~m}$ (Figure 3A), to the Marmara Sea at $\sim-70 \mathrm{~m}$, to the gradually rising Aegean Sea.

The isolated mid-shelf delta ( $\Delta 2$ of Hiscott et al. 2002) at the southern end of the Bosphorus Strait is here reinterpreted to have formed during the 16-14.7 ky BP outflow event (Figures 5C and 6). The youngest topset-toforeset transition of this delta is at a modern elevation of $-69 \mathrm{~m}$. Ideally, the topset elevation should be several meters below the contemporaneous sea level. Given potential uncertainty in the estimate of the depth of the Dardanelles sill, and possible uplift of $\Delta 2$ because of proximity to the North Anatolian Transform Fault (C. Yaltırak, personal communication 2004), the agreement between the topset-to-foreset elevation $(-69 \mathrm{~m})$ and the spill depth $(\sim-70 \mathrm{~m})$ is remarkably good. When the first phase of Black Sea outflow ceased at 14.7 ky BP (Ryan et al. 2003), $\Delta 2$ was abandoned and a marine drape filled depressions adjacent to the delta lobe (Figure 6 between $\beta 4$ and $\beta 3$ ). At this time, the Marmara Sea was a landlocked lake, and evaporation from 14.7-12 ky BP caused its surface 

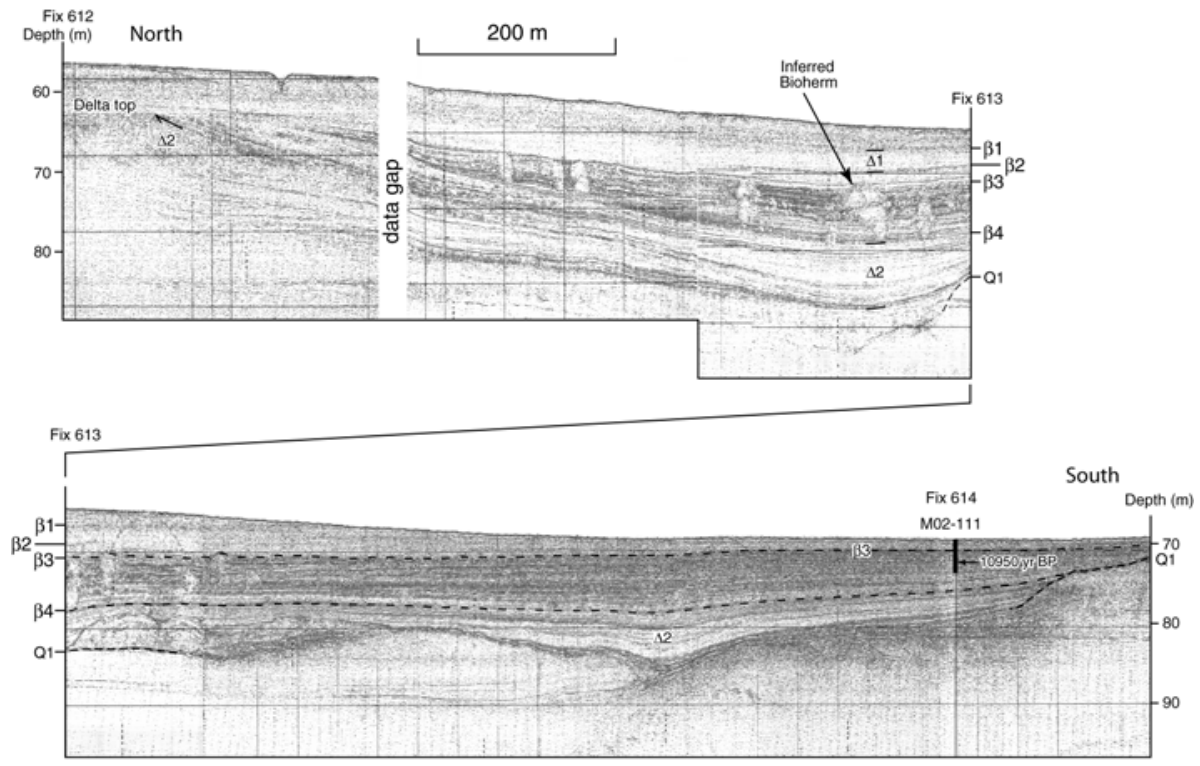

Figure 6. Huntec deep-tow boomer profile (location in Figure 5A) across $\Delta 2$, showing reflections $\beta 1-\beta 4$ and Q1 defined by Hiscott et al. (2002). Strata equivalent to $\Delta 2$ are confined between reflections $\beta 4$ and $\mathrm{Q} 1$, whereas the younger $\Delta 1$ is represented in this profile only by its prodelta deposits between reflections $\beta 1$ and $\beta 2$. The mounds along the $\beta 3$ surface are interpreted as algalserpulid bioherms. Core M02-111 penetrates well below $\beta 3$; facies, radiocarbon dates, and picks of reflectors are shown in Figure 7B.

to drop to -100 m (Aksu et al. 1999) forming the $\beta 3$ unconformity in the vicinity of $\Delta 2$. Our own observations on the shelf of the southwestern Black Sea confirm a lowstand of -120 m during the same time period (Aksu et al. 2002b), so that there would have been no connection or water exchange between the Black Sea and the landlocked Marmara Sea. Proxy paleoclimate data are consistent with dry conditions at this time to account for the net evaporation (Mudie et al. 2002b).

During the $16-14.7 \mathrm{ky}$ BP outflow event, sands and gravels at the shallow western end of the Marmara Sea were reworked into west-directed bedforms (Aksu et al. 1999). We recently cored through the homogeneous mud drape that overlies these bedforms and recovered, from below the mud, a unit of gravelly sand of which $10-20 \%$ consisted of $<2 \mathrm{~cm}$ pebbles (Figures 8 and 7A). Marine shells at the base of the mud provide a minimum age of 11,340 yr BP for this reworked gravel (Table 1), but the gravel itself was non-fossiliferous and potentially several thousand years older. It could have been formed contemporaneously with $\Delta 2$ during the $~ 16-14.7$ ky BP outflow event when the Marmara Sea stood at -65 to $-70 \mathrm{~m}$. No erosional break was found within the mud drape, contrary to what would be expected if there had been a violent 


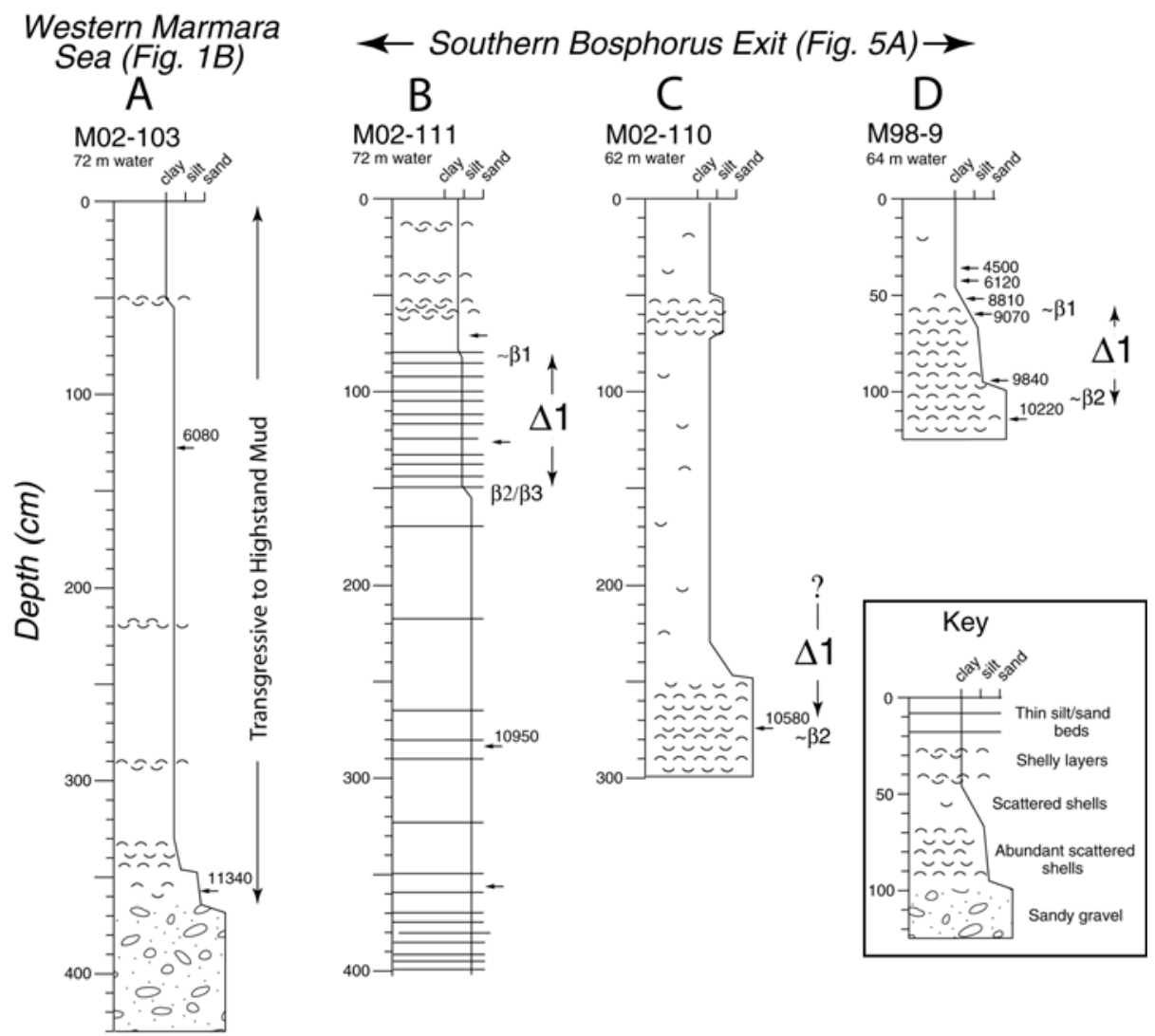

Figure 7. Graphic core logs for three new cores not described in earlier publications, and the previously described Core M98-9 (see also Figure 10). Radiocarbon dates are presented more fully in Table 1. Interpreted reflector depths are determined from seismic profiles at each core site and from changes in lithology.

northward flow of Mediterranean water in the early Holocene as proposed by Ryan et al. (1997), Ryan and Pitman (1998) and Ryan et al. (2003).

At 12 ky BP, the world ocean had risen to the depth of the Dardanelles sill, and Mediterranean waters rapidly refilled the small Marmara basin to its sill depth (-65 to $-70 \mathrm{~m})$. Because the Black Sea was still isolated from the world ocean at this time (Figure 3A) (Ryan et al. 2003), the Marmara Sea developed into an arm of the Aegean Sea and became fully saline. Its shelves were colonized by algal-serpulid bioherms, which are found on the crests of submerged barrier islands and bedforms in the western Marmara Sea, and on the $\beta 3$ unconformity south of Bosphorus Strait (Figure 6) (Hiscott et al. 2002). The hiatus in Black Sea outflow during the interval $14.7-10 \mathrm{ky}$ BP provided a unique environment for bioherm development that has not recurred since. 
Table 1. Radiocarbon ages reported as uncalibrated conventional ${ }^{14} \mathrm{C}$ dates in years BP (halflife of 5568 years; errors are $68.3 \%$ confidence limits). Data are for cores considered in this paper only; see Aksu et al. (2002b) for additional dates.

\begin{tabular}{|c|c|c|c|c|c|c|c|}
\hline Core & $\begin{array}{c}\text { Depth } \\
\text { (cm) }\end{array}$ & Latitude & Longitude & $\begin{array}{c}\text { Water } \\
\text { Depth } \\
\text { (m) }\end{array}$ & Dated Material & $\begin{array}{c}\text { Radiocarbon } \\
\text { years BP }\end{array}$ & $\begin{array}{c}\text { Lab } \\
\text { Number }\end{array}$ \\
\hline \multirow[t]{6}{*}{ M98-9 } & 35 & $40^{\circ} 55.36^{\prime} \mathrm{N}$ & $28^{\circ} 56.80^{\prime} \mathrm{E}$ & -64 & Anomia spp. & $4500 \pm 60$ & TO-7789 \\
\hline & 42 & & & & Nuclea nucleus & $6120 \pm 70$ & TO-8455 \\
\hline & 52 & & & & Varicorbula gibba & $8810 \pm 100$ & TO-8456 \\
\hline & 60 & & & & Turritella spp. & $9070 \pm 70$ & TO-7790 \\
\hline & 94 & & & & Turritella spp. & $9840 \pm 80$ & TO-7791 \\
\hline & 113 & & & & Mytilus spp. & $10,220 \pm 70$ & TO-7792 \\
\hline \multirow[t]{2}{*}{ M98-12 } & 50 & $40^{\circ} 50.54^{\prime} \mathrm{N}$ & $27^{\circ} 47.68^{\prime} \mathrm{E}$ & -549 & Bivalve fragment & $4200 \pm 100$ & TO-8457 \\
\hline & 130 & & & & Nuculacea spp. & $10,660 \pm 130$ & TO- 8458 \\
\hline \multirow[t]{2}{*}{ M02-103 } & 128 & $40^{\circ} 34.85^{\prime} \mathrm{N}$ & $27^{\circ} 27.81^{\prime} \mathrm{E}$ & -72 & Turritella spp. & $6080 \pm 80$ & TO-11148 \\
\hline & 358 & & & & $\begin{array}{l}\text { Parvicardium } \\
\text { exiguum }\end{array}$ & $11,340 \pm 80$ & TO-11011 \\
\hline M02-110 & 275 & $40^{\circ} 55.61^{\prime} \mathrm{N}$ & $28^{\circ} 57.10^{\prime} \mathrm{E}$ & -62 & Anadara spp. & $10,580 \pm 100$ & TO-11149 \\
\hline M02-111 & 284 & $40^{\circ} 55.31^{\prime} \mathrm{N}$ & $28^{\circ} 36.13^{\prime} \mathrm{E}$ & -72 & Anadara spp. & $10,950 \pm 100$ & TO-11150 \\
\hline A91-20 & 120 & $38^{\circ} 26.00^{\prime} \mathrm{N}$ & $24^{\circ} 58.00^{\prime} \mathrm{E}$ & -630 & foraminifera & $9830 \pm 70$ & TO-3742 \\
\hline
\end{tabular}

A second pulse of brackish-water outflow from the Black Sea began perhaps as early as $\sim 11$ ky BP (Ryan et al. 2003) but certainly by $10 \mathrm{ky}$ BP (Aksu et al. 2002a). This outflow suppressed the growth of algal-serpulid bioherms and reactivated the deposition of a mud drape across $\Delta 2$ and the $\beta 3$ unconformity. Soon, the outflow intensified and a second mid-shelf delta $(\Delta 1$ of Hiscott et al. 2002) began to develop on the shelf (Figures 5B and 9), precisely at the elevation of global sea level from 10-9 ky BP (Fairbanks 1989). At $10 \mathrm{ky}$ $\mathrm{BP}$, the Marmara Sea was still some $20 \mathrm{~m}$ below the depth of the Bosphorus sill, so the burgeoning Black Sea fed a brackish-water river that nourished $\Delta 1$. This delta is unusual because it grew upward into the rising sea level, so that the topset-to-foreset transition is shallowest in the youngest deposits (Figure 9). The radiocarbon age of the reflector that defines the top of $\Delta 1$ is $8810-9070 \mathrm{BP}$ (Table 1, Figure 7D), whereas the base of the delta is younger than $\beta 3$ and therefore younger than 10,950 BP (Figures $7 \mathrm{~B}$ and 6). This base is dated at $\sim 10,580$ BP in core M02-110 (Table 1, Figures 7C and 9).

Core M02-110 sampled the bottomsets of $\Delta 1$ (Figure 9) and provides a much more reliable indication of the age of the delta than the extrapolated age previously published by us for core M98-9 (see criticism in Ryan et al. 2003). This second episode of Black Sea outflow, which created $\Delta 1$, was triggered by the swelling discharges of the Danube, Dniester, Southern Bug, Dnieper, and Don Rivers, augmented at times by Volga River discharge through the Manych outlet (Mamedov 1997; Chepalyga, this volume). The combined drainage area 
14

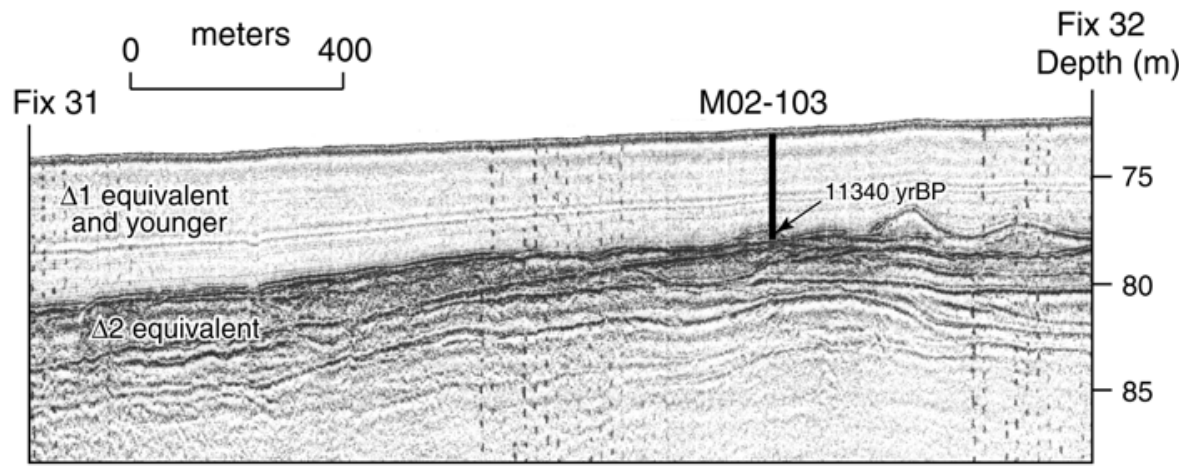

Figure 8. Huntec deep-tow boomer profile showing typical characteristics of the essentially homogeneous mud drape that overlies lowstand deposits around the Marmara Sea. The position of Core M02-103 on Figure 1B provides location. Core facies and ages are given in Figure 7B and Table 1 . The highly reflective deposits below the cored interval are interpreted as fluviatile to shallow marine sands and gravels. Local crossbedding in this sediment indicates westward paleoflow (Aksu et al. 1999).

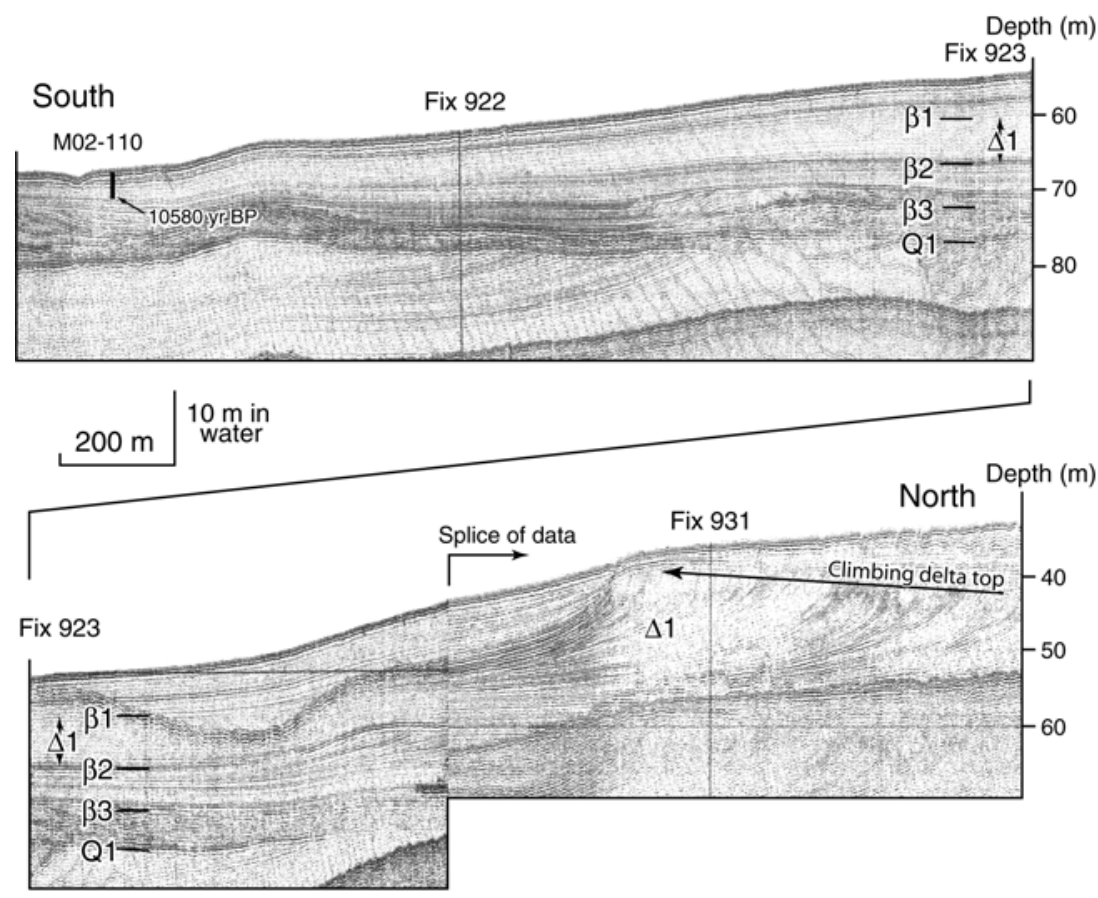

Figure 9. Huntec deep-tow boomer profile (location in Figure $5 \mathrm{~A}$ ) showing $\Delta 1$ delta front and prodelta, and the position of Core M02-110. The topset-foreset transition (offlap break) climbs consistently from right to left in the lower panel (north to south), indicating progradation during a relative sea-level rise. Foresets dip $\sim 2^{\circ}$. Core M02-110 penetrates approximately to $\beta 2$ at the base of the $\Delta 1$ succession; facies, radiocarbon dates, and picks of reflectors appear in Figure $7 \mathrm{C}$. 
of these six rivers equals that of the Mississippi-Missouri system in America.

Ryan (2003) challenged our assertion that $\Delta 1$ and $\Delta 2$ were fed by Black Sea outflow through the Bosphorus Strait, suggesting instead that they are the deltas of either the Kağıthane Deresi or the Kurbağalı Dere, two small rivers that presently drain into the Marmara Sea near Istanbul (Figure 5A). This suggestion is untenable because the modern sediment discharge rates of these rivers are so small that it would take $\sim 25,000-70,000$ years to construct $\Delta 1$ (Table 2), a time span clearly at odds with the duration of delta progradation ( $\sim 1000$ years from $\sim 10-9$ ky BP). Hiscott et al. (2002) calculated $\Delta 1$ sediment mass at $6.2 \times 10^{8} \mathrm{t}$.

Table 2. Comparison of water and sediment discharges of selected rivers with the modern Bosphorus (EIE 1999).

\begin{tabular}{|c|c|c|c|}
\hline $\begin{array}{c}\text { River or } \\
\text { Strait } \\
\end{array}$ & $\begin{array}{c}\text { Drainage } \\
\text { Area }\left(\mathbf{k m}^{2}\right)\end{array}$ & $\begin{array}{c}\text { Mean Discharge } \\
\left(\mathrm{m}^{3} \mathrm{~s}^{-1}\right)\end{array}$ & $\begin{array}{c}\text { Suspended Sediment } \\
\text { Discharge }\left(\mathrm{t} \mathrm{yr}^{-1}\right)\end{array}$ \\
\hline Kocasu & 21,611 & 151 & $1986 \times 10^{3}$ \\
\hline Kurbağalı Dere & 41 & 1.6 & $9 \times 10^{3}$ \\
\hline Kağıthane Deresi & 183 & 3.3 & $24 \times 10^{3}$ \\
\hline Modern Bosphorus & N/A & $\sim 10,000$ & surface outflow only \\
\hline
\end{tabular}

\subsection{Evidence for Sustained Black Sea Outflow 10-3 ky BP}

We have published several papers outlining why Black Sea outflow into the Aegean Sea through the Marmara Sea must have started 10 ky BP and persisted to the present day. Black Sea outflow from $\sim 10-6.4$ ky BP is absolutely required to account for the intense water-column stratification and dysoxyia that accompanied deposition of contemporaneous sapropels S1 in the Aegean Sea (Aksu et al. 1995) and M1 in the Marmara Sea (Çağatay et al. 2000; Aksu et al. 2002a, c). This assertion has not been seriously challenged or rebutted by Ryan and coworkers, even though it is a fundamental inconsistency with their flood hypothesis. We remind the reader of the analogy of counting spectorators as they leave a stadium in order to ascertain attendance. The large volumes of brackish water that entered the Marmara Sea from 10-6.4 ky BP are an unambiguous indicator of persistent Black Sea outflow, because there is absolutely no other conceivable source for this low-salinity influx. Today, the volume of the semi-marine Black Sea outflow is $~ 50$ times the combined volume of all rivers entering the Marmara Sea.

Benthic foramininfera allow estimation of bottom water oxygenation, using the benthic foraminiferal oxygen index (BFOI) of Kaiho (1994). Low values indicate dysoxic conditions at the seabed below a stratified water column (Kaminski et al. 2002). In the central Marmara Sea and northern Aegean Sea (Cores M98-12 and A91-20), low values confirm profound stratification through the 10-6.5 ky BP interval (Figure 10). Dinoflagellate cysts Brigantedinium simplex and Spiniferites cruciformis (Figure 10) are sensitive indicators of low- 
salinity marine and fresh/brackish water conditions, respectively, and can be used to trace water masses. Mildly brackish water conditions prevailed in the Marmara Sea before its reconnection with the Aegean at 12 ky BP (Core M9812) and accompanied the development of sapropel in the Aegean Sea from 10-6.5 ky BP (Core A91-20) (Figure 10). The only reasonable source of significant amounts of brackish water in the northern Aegean Sea is outflow from the Black Sea because small rivers in the region have insufficient catchments and discharges. This ouflow is confirmed in Core M98-12 by a broad peak in Peridinium ponticum (endemic to the Black Sea) from 11-6 ky BP (Mudie et al. 2002a). Thus Black Sea overflow began prior to 8.4 ky BP and continued into the Holocene.

Palynology indicates increased terrigenous supply of pollen from rivers beginning at 11-10 ky BP and declining in the central Marmara and Aegean Seas by $\sim 6$ ky BP (Cores M98-12 and A91-20) (Mudie et al. 2002b). The persistent moderate pollen abundances at the southern exit from the Bosphorus Strait (Core M98-9) since 9.5 ky BP are ascribed to pollen input into the Black Sea from major European rivers, and throughput of this pollen via outflow to the Marmara Sea (Figure 10).

Paleo sea-surface salinity (SSS) was calculated (as explained in Aksu et al. 1995) using (1) a Mediterranean-based transfer function to determine seasurface temperatures, (2) the paleotemperature equation of Shackleton (1974) to determine $\delta^{18} \mathrm{O}$ of the ancient surface waters, and (3) empirical data to relate these latter values to salinity. In the Aegean and central Marmara Seas, SSS dropped dramatically during deposition of approximately time-equivalent sapropels S1 and M1 (Cores A91-20 and M98-12). SSS at the southern exit from the Bosphorus Strait was depressed from 10-9 ky BP, consistent with high abundances of the fresh/brackish-water dinocyst $S$. cruciformis.

Elevated TOC (total organic carbon) in Aegean Sea sediments coincides with lowered SSS, increased terrigenous supply of pollen, and increased stratification of the water column (low BFOI). In the Marmara Sea, TOC has been persistently high since $\sim 11-10 \mathrm{ky} \mathrm{BP}$, with a moderate decrease since $\sim 5-3$ ky BP away from the Bosphorus exit (e.g., Core M98-12). Pollen abundance mimics these trends, confirming the terrestrial origin of the organic matter (Mudie et al. 2002b; Abrajano et al. 2002). The core data indicate development of a brackish-water surface layer in the Marmara Sea by 11-10 ky BP, with the strongest water-column stratification from $~ 10-6.5 \mathrm{ky} \mathrm{BP}$, when widespread sapropel developed in the gateway area. The $\sim 11$ ky BP onset of stratification is consistent with the timing of the second outflow event of Ryan et al. (2003), but its continuation well beyond $\sim 10 \mathrm{ky} \mathrm{BP}$ is not (Figures 3A and 4). Instead, this continuation requires unabated Black Sea outflow as proposed by Aksu et al. (2002a) and Hiscott et al. (2002). 

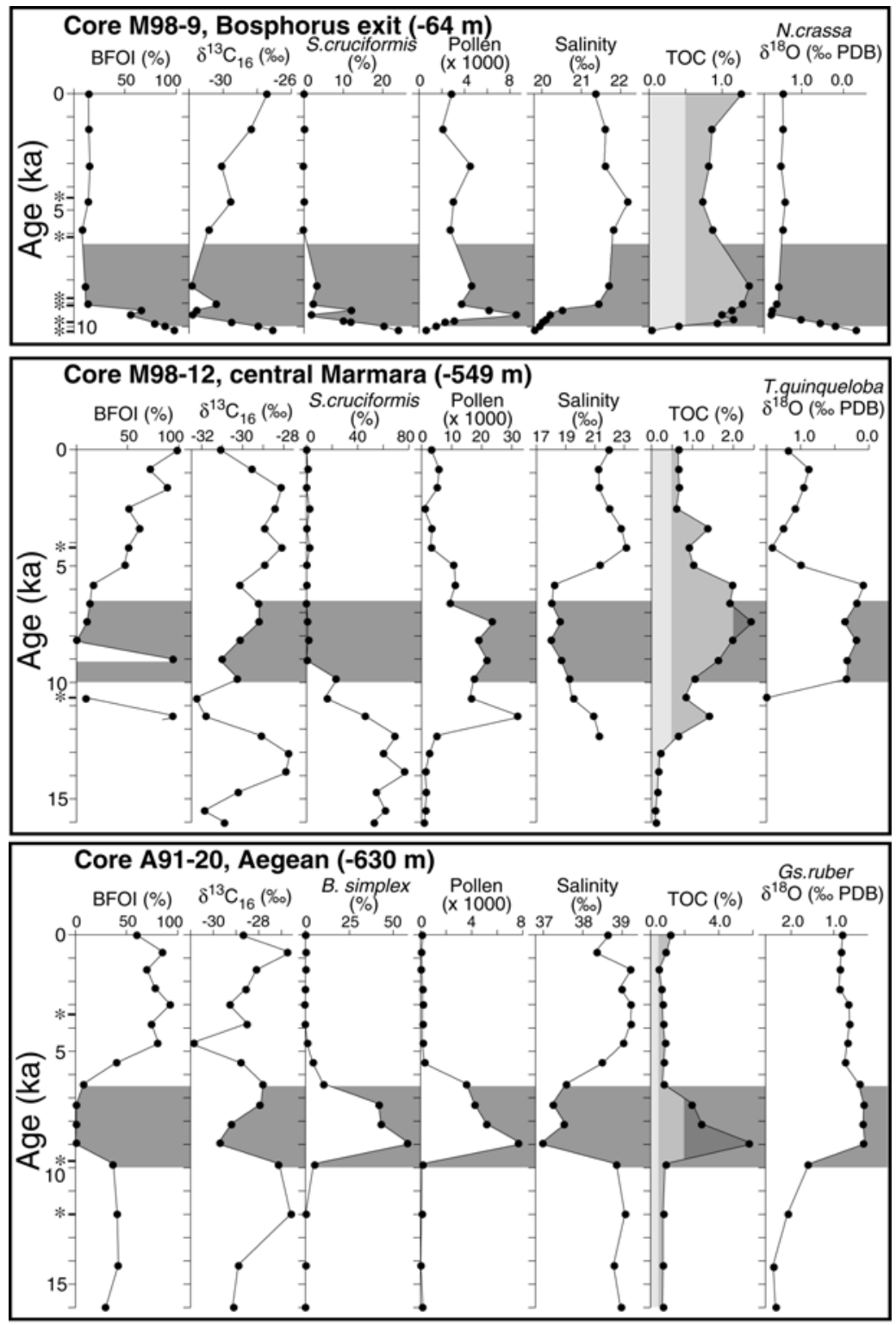

Figure 10. Downcore plots of key proxy variables; core locations in Figures 1B and 5A. Water depth at each site is indicated (e.g., -630 m). Samples were transposed into a time domain using radiocarbon dates tabulated in Aksu et al. (2002c), and the oxygen-isotope and ash record in Core A91-20. Control points are marked by asterisks $(*)$ along the age scale. Where filled dots (sample positions) cluster, the accumulation rate was highest (e.g., deltaic strata at the base of Core M98-9). Where filled dots are missing for some variables, the species required for determinations were absent (e.g., T. quinqueloba before $\sim 10$ ky BP for Core M98-12). The gray band from 10-6.5 ky BP coincides with sapropel deposition and significant changes in several proxy variables. 
Today, the semi-marine-water surface layer that is responsible for bottom-water dysoxyia originates entirely from Black Sea outflow. Local riverine input into the Marmara Sea is $~ 2 \%$ of the Black Sea outflow, and it is entirely inadequate to explain the profound water-column stratification that has prevailed in the Marmara Sea since 10 ky BP. There was no interruption in the degree of stratification at $\sim 8.4 \mathrm{ky} \mathrm{BP}$, as would surely have accompanied a catastrophic flood. Similarly, the failure of open-marine foraminifera to colonize the Marmara Sea at $~ 8.4$ ky BP is inconsistent with a major flood (Aksu et al. 2002c; Kaminski et al. 2002).

\subsection{Evidence Against a Dry Early Holocene Climate}

In their revised catastrophic flood model, Ryan et al. (2003) proposed that from 10-8.4 ky BP, water level in the isolated Black Sea dropped by $\sim 70$ $\mathrm{m}$ from $\sim-25 \mathrm{~m}$ to $\sim-95 \mathrm{~m}$ (Figure 3A). They presumed that the drawdown of the sea surface occurred in a manner "akin to the Caspian Sea," where evaporation exceeded all inputs during warm periods of the Quaternary (Chepalyga 1984), although Mamedov (1997) reported that sea level in the Caspian was reduced by only about 15 m during the period of $\sim 10-7.8 \mathrm{ky} \mathrm{BP}$. Ryan and Pitman (1998) initially cited unpublished palynological data from cores collected along the Bulgarian coast as evidence for the persistence of cold, dry conditions similar to those of the Younger Dryas until 7.5 ky BP. They later presented a summary of Atanassova's pollen stratigraphy (1995) to bolster their argument for an early Holocene interval of cold, dry climate in the western Black Sea, characterized by herb-grass vegetation (Figure 11 of Ryan et al. 2003).

In contrast, Mudie et al. (2002b, their Table 2) summarized palynological data from lakes in a wide area west and south of the Black Sea and showed that oak-pistacio (Quercus-Pistacia) forests were present over most of the region by $10 \mathrm{ky} \mathrm{BP}$, although local desert-steppe vegetation persisted until $\sim 7$ ky BP in the southeast, from Lake Van to the Caspian Sea. These forests indicate the early establishment of mesic climatic conditions characterized by $>600 \mathrm{~mm}$ /year of precipitation (P) in excess of evapotranspiration (E), as is presently found in most of central and western Europe. Pollen diagrams for lakes in Bulgaria (Bozilova and Beug 1994) and for a long core from the Bay of Sozopol (Filipova-Marinova and Bozilova 2002) also show the presence of mesic deciduous oak forest before $8.4 \mathrm{ky} \mathrm{BP}$, which accords with the establishment of a mixed coniferous-deciduous forest in Romania by about 9.5 ky BP $(10,750$ calBP; Björkman et al. 2003). Velichko et al. (1997) also report that broadleafed oak, lime, and elm trees were established in parts of the central Russian plains by $9.6 \mathrm{ky} \mathrm{BP}$, following an interval between 9.9 and $9.5 \mathrm{ky}$ BP during which winters were about $2^{\circ} \mathrm{C}$ colder. 

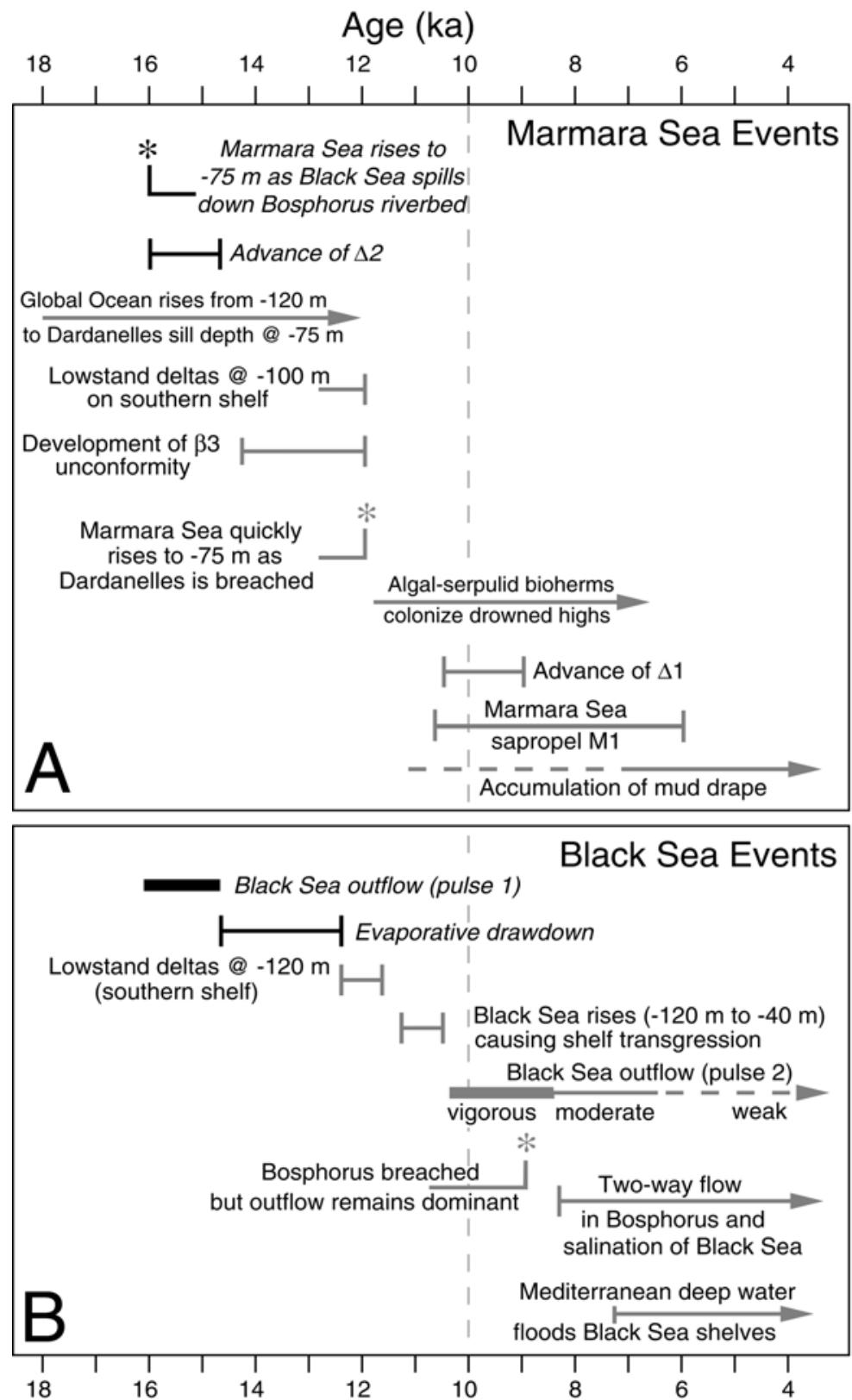

Figure

11 .

Summary of the paleoceanographic history of the Marmara Sea (A) and Black Sea (B). Timing and duration of some of the events colored gray are slightly modified from Hiscott et al. (2002, their figure 15) in order to conform with the Outflow Hypothesis II (Figure 4). Events in black with italics labels are additions to our earlier work. Asterisks $(*)$ indicate events which occurred very rapidly, in tens of years to $\sim 100$ years. The Dardanelles sill depth is specified as $-75 \mathrm{~m}$ rather than the modern value of $-70 \mathrm{~m}$ to account for ongoing uplift of the area around the strait (Yaltırak et al. 2002). 
Mudie et al. (2002b) studied marine pollen data from a deep-water core in the south-central Black Sea and from three cores in the Marmara Sea. They found an interval of ameliorating climatic conditions from 10-9 ky BP when a broadleafed oak forest tolerant of colder $\left(-2^{\circ} \mathrm{C}\right)$ winters but requiring $>600 \mathrm{~mm}$ per year excess moisture replaced a pre-existing, drought tolerant steppe-forest and herb-grass-shrub vegetation. They also documented increased warmth and humidity supporting a mesic, temperate, deciduous, oak-pistacio forest from 9 ky BP to the present, which was interrupted from $\sim 8-3.2$ ky BP by a climatic optimum with warmer and wetter conditions than today. Their reconstruction of the Black Sea area is consistent with precipitation and evaporation levels that Dolukhanov (1997) outlines for eastern Europe since 11 ky BP, and it also matches the quantitative temperature and precipitation reconstructions of Velichko et al. (1997) for the central Russian plains from $50^{\circ}-60^{\circ} \mathrm{N}$.

Since the early Holocene, the Pontic Basin has apparently supported a range of vegetation types broadly similar to those found today (see Mudie et al. 2002b). The modern vegetation zones include the western subregion of Mediterranean woodland with a Csb climate (mesothermal, summer dry), the southern subregion of mesic Euxinian-type forest with a Cfa climate (humid subtropical conditions with year-round precipitation), and aridic steppe or savannah grassland subregions in the north and east with a semi-arid BSk climate (see Finch et al. 1957, for details). The eastern side of the Caspian Sea is a midlatitude desert with a BSw climate. The Cs and Ca climate zones have an excess of precipitation over potential evaporation; the dry climate BS zones have a deficiency of rainfall (Finch et al. 1957).

Ryan et al. (2003) advocated using the water-level excursions of the Caspian Sea as a guide for interpreting the Late Quaternary changes in climate and sea level in the Black Sea basin. At the simplest level, the extreme aridity east of the Caspian Sea makes it a questionable model for their proposed 10-8.4 ky BP drawdown in the Black Sea. Nevertheless, the underlying principles that control the behavior of the Caspian Sea (Chepalyga 1984) can easily be applied to the Black Sea basin, even if the boundary conditions differ. The Black Sea basin presently has a large excess of river inflow, R, over net evaporation, P-E. ( $\mathrm{P}$ and $\mathrm{E}$ are annual precipitation and evaporation over the surface of the water body, respectively. If P-E = a positive quantity, the difference is called net precipitation; if negative, we use net evaporation). This large fresh-water supply from the Danube, Dniester, Dnieper, Southern Bug, and Don Rivers drives a net outflow of $\sim 300 \mathrm{~km}^{3} /$ year through the Bosphorus Strait (Özsoy et al. 1995; Polat and Tuğrul 1996). To evaluate the climatic implications of the proposal of Ryan et al. (2003) for a rapid early Holocene sea-level fall in the Black Sea, let us assume a closure of the Bosphorus at $10 \mathrm{ky}$ BP and try to account for a subsequent drop in water level of $\sim 70 \mathrm{~m}$ in the brief cold, dry interval from 10-9 ky BP. After 9 ky BP, our data indicate a climate much like today and we see no reason to expect a negative water balance in the Black Sea at that time. If the 
Black Sea was indeed low at $\sim 9$ ky BP, then we would predict no further net evaporation; instead, water level might have been static or slowly rising.

We used the Black Sea bathymetric map to calculate that a water loss of $\sim 25,600 \mathrm{~km}^{3}$ is required to depress the sea surface from $-25 \mathrm{~m}$ to $-95 \mathrm{~m}$. The average annual loss rate over a 1000-year interval would therefore have been 25 $\mathrm{km}^{3}$ if the Ryan et al. (2003) proposal of evaporative drawdown is valid. In a closed basin, a water-volume loss must be explained by an annual excess of output (evaporation, E) over inputs (precipitation, $\mathrm{P}$, and river inflow, R):

$$
\Delta \mathrm{V}=\mathrm{R}+\mathrm{P}-\mathrm{E}
$$

If we set $\Delta \mathrm{V}$ to $-25 \mathrm{~km}^{3} /$ year, and assume that river input at $\sim 10 \mathrm{ky}$ BP was twothirds of the modern $\sim 350 \mathrm{~km}^{3} /$ year (to account for drier conditions), then a P-E value of $\sim-258 \mathrm{~km}^{3} /$ year will satisfy the mass-balance equation for $\Delta \mathrm{V}$.

P-E for the modern Black Sea has been estimated by many researchers. The average of nine estimates published between 1970 and 1992 is $-117 \mathrm{~km}^{3} /$ year (Jaoshvili 2002, his Table 5.1 and references therein). A parameter that can be compared among the modern Black Sea, the 10 ky BP Black Sea, and other Eurasian marginal seas and lakes, is the net potential evaporation (NPE), which is obtained by normalizing P-E to the surface area of the water body: NPE $=(\mathrm{P}-$ E)/area. For the modern Black Sea (area $=441,000 \mathrm{~km}^{2}$ ), NPE $=-0.27 \mathrm{~m} /$ year. For the $\sim 10-8.4$ ky BP Black Sea described above (average area during fall from $-25 \mathrm{~m}$ to $-90 \mathrm{~m}$ elevation $\sim 368,000 \mathrm{~km}^{2}$ ), NPE $=-0.70 \mathrm{~m} /$ year. For comparison, Table 3 lists NPE values for selected marginal seas and enclosed water bodies of central Eurasia. The Red Sea and Persian Gulf are at the most evaporative end of the spectrum, with NPE of $\sim-2 \mathrm{~m} /$ year.

For the Black Sea to have dropped to a lowstand of $\sim-95 \mathrm{~m}$ in 1000 years with $\sim 66 \%$ of its modern fluvial input, the evaporative conditions over the sea surface had to be intermediate between those of the modern Caspian and Aegean seas (Table 3), leading to a net potential evaporation more than double the modern value. The Caspian region has a much drier, continental climate than the Black Sea, and the Aegean region is much warmer year-round, explaining the significantly higher rates of evaporation in both these areas relative to the Black Sea basin. Other researchers (e.g., Chepalyga 1984) assume changes in P-E of perhaps 20-30\% during transitions from forest to steppe conditions, much less than the factor of two required to explain a 10-9 ky BP rapid evaporative lowering of the Black Sea. As a result, we conclude that the evaporative drawdown proposed by Ryan et al. (2003) cannot be explained by reasonable boundary conditions. The only alternative scenario that might permit such a rapid drawdown without recourse to unrealistic aridity would be a reduction in river flow to far less than $66 \%$ of modern discharges. However, neither the pollen data nor lake-status studies for the early Holocene (Harrison et al. 1996) support such a profound reduction in river flow throughout central and eastern 
Europe at that time.

Table 3. Estimates of net potential evaporation (NPE) for marginal and inland seas

\begin{tabular}{cccccc}
\hline Name & Age & $\begin{array}{c}\text { P-E } \\
\left(\mathbf{k m}^{3} / \mathbf{y r}\right)\end{array}$ & $\begin{array}{c}\text { Area } \\
\left.\mathbf{( k m}^{2}\right)\end{array}$ & $\begin{array}{c}\text { NPE } \\
(\mathbf{m} / \mathbf{y e a r})\end{array}$ & Source \\
\hline Black Sea & modern & -117 & 441,000 & -0.27 & $\begin{array}{c}\text { 9 estimates } \\
\text { (Jaoshvili 2002) }\end{array}$ \\
Aegean Sea & modern & -104 & 174,000 & -0.60 & Josey (2003) \\
Black Sea & $\sim 10$ ky BP & -258 & 368,000 & -0.70 & $\begin{array}{c}\text { This paper, to evaluate } \\
\text { proposed drawdown } \\
\text { of Ryan et al. (2003) }\end{array}$ \\
Caspian Sea & $\begin{array}{c}1900- \\
1985\end{array}$ & -296 & 371,000 & -0.80 & $\begin{array}{c}\text { Golubev (1998), Kosarev } \\
\text { and Makarova (1988) }\end{array}$ \\
Aral Sea & $\begin{array}{c}1926- \\
\text { 1960 }\end{array}$ & -56 & 65,780 & -0.85 & Micklin (1988) \\
Persian Gulf & modern & -482 & 241,000 & $\sim-2.00$ & Johns et al. (2003) \\
Red Sea & modern & -924 & 440,000 & -2.10 & Sofianos et al. (2002)
\end{tabular}

As a final cautionary note regarding paleoclimate models, it is now evident that the interpretation of early Holocene herb-grassland vegetation requires careful re-evaluation in light of quantitative studies of the Younger Dryas Artemisia:Chenopod pollen signal, formerly interpreted as indicating cold, dry conditions (Prentice et al. 1992). The ratio of these herbs was formerly used as a drought index, but it is now clear that the same pollen ratios can result from an increase (not decrease) in surface winter runoff. This finding has especially important implications when trying to track the switch from steppe to steppeforest vegetation based on pollen signals.

\section{NON-CATASTROPHIC EXPLANATION OF

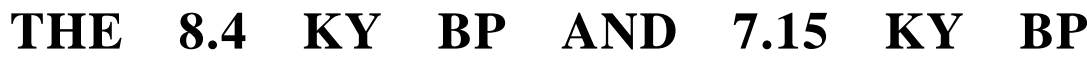 PALEOCEANOGRAPHIC SHIFTS}

There is encouraging convergence between the Flood Hypothesis (Ryan et al. 1997; Ryan and Pitman, 1998; Ryan et al. 2003) and our Outflow Hypothesis II (Figure 4). The suggestion of a significant time lag between the first marine connection at the Bosphorus and colonization of the Black Sea shelves by euryhaline fauna (Aksu et al. 1999 and 2002a, based on arguments in 
Lane-Serff et al. 1997) was incorporated by Ryan et al. (2003) into their modified flood hypothesis (Figure 3A), so it is no longer an issue for debate. We have incorporated the two periods of Black Sea spillover identified by Ryan et al. (2003) into our modified outflow hypothesis (Figure 4). Where we continue to disagree is on the post-10 ky BP history of the Marmara Sea Gateway. Ryan et al. (2003) and Major (2002) base their requirement for a catastrophic inundation of the Black Sea at 8.4 ky BP entirely on a dramatic shift in the Srisotopic composition of mollusc shells to open-marine values. We see no need for such an interpretation because the isotopic shift can also be the result of a time lag in the connection process.

Lane-Serff et al. (1997) described the way in which two-way flow becomes established in narrow and shallow straits, using the Bosphorus channel as their example. From 10-9 ky BP, the Black Sea was significantly higher than the Marmara Sea and the Bosphorus acted like a river (Figure 4), so there was no possibility of open-ocean water reaching the Black Sea to change its Srisotopic signature. Once the Marmara Sea reached the Bosphorus sill depth at $\sim 9$ ky BP, the depth of water in the strait would have been too shallow to allow sustained two-way flow. The presence of small quantities of brackish-water dinoflagellate cysts in the southern Black Sea by 9 ky BP (Mudie et al. 2004) may indicate that some Mediterranean water periodically succeeded in reaching the Black Sea by that time, transporting dinoflagellate cysts northward. However, this volume was so small that the chemical composition of Black Sea shelf waters did not change (Major 2002).

The first clear evidence of marine dinoflagellate cysts (Spiniferites mirabilis) in the Black Sea occurs at $\sim 8.5$ ky BP (Mudie et al. 2004). Kaminski et al. (2002) independently concluded from benthic foraminiferal data that effective and sustained two-way flow was not established until $~ 8.5 \mathrm{ky} \mathrm{BP}$. This dating coincides almost exactly with the dramatic shift in the Sr-isotopic composition of Black Sea molluscs that Major (2002) and Ryan et al. (2003) ascribe to a catastrophic inundation of the Black Sea. Instead, we propose that the 8.4 ky BP event simply marks the onset of sustained two-way flow, permitting sufficient Mediterranean water into the Black Sea basin to induce a rapid change in the Sr-isotopic composition of its waters. Today, the Black Sea has a sharp chemocline that separates more saline ( $22 \%$ o) and anoxic basinal waters from less saline ( $18 \%$ ) and oxygenated surface waters. A comparable chemocline likely characterized the Black Sea as it began to receive saline inflow from the Marmara Sea. Disruption of this early stratification, perhaps by a major storm or set of storms, might have been enough to trigger an homogenization of Sr-isotopic values between the deep and surface water masses at $~ 8.4$ ky BP. There is, we believe, no need to advocate a catastrophic flood to affect such a change. 


\section{CONCLUSIONS}

The Outflow Hypothesis II (Figure 4) represents a rethinking and consolidation of our interpretation of the evolution of the Marmara Sea Gateway since 16 ky BP, incorporating two pulses of Black Sea outflow suggested by Ryan et al. (2003) and Major (2002) for the period 16-10 ky BP. For younger times, we reject the notion that the level of the Black Sea again fell to $\sim-90 \mathrm{~m}$, followed by a catastrophic incursion of marine water at $\sim 8.4 \mathrm{ky} \mathrm{BP}$. Instead, our previously published multiproxy data from cores in the Marmara Sea, and interpretation of seismic facies in high-resolution boomer profiles, point conclusively to unabated Black Sea outflow from $10.5 \mathrm{ky}$ BP to the present. This outflow formed a cascading river from 10.5-9 ky BP until the level of the world ocean (and Marmara Sea) reached the elevation of the sill in the Bosphorus Strait. From 9-8.4 ky BP, the outflow was sufficiently strong to prevent any measurable amount of saline water from entering the Black Sea, and so during this time, there was only one-way (outward) flow through the strait. Beginning at $~ 8.5$ ky BP, two-way flow was established leading quickly to (1) a sharp shift in the Sr-isotopic composition of the Black Sea (Major, 2002), and (2) arrival of the first Mediterranean immigrants (dinoflagellates and benthic foraminifera). Considerably later at 7.15 ky BP, the salinity of shelf waters in the Black Sea became high enough to permit euryhaline molluscs to thrive.

Our perception of the history of the gateway is summarized in Figure 11, modified from an earlier version published by Hiscott et al. (2002, their Figure 15). Except for minor shifts in the timing of events needed to conform more closely to the Outflow Hypothesis II, the only substantive change is the incorporation of a 16-14.7 ky BP pulse of outflow which nicely accounts for the development of the older $\Delta 2$ south of the Bosphorus Strait. Previously, we had interpreted $\Delta 2$ to be much older (marine isotopic stage 3 ), but new radiocarbon dates show that the $\beta 3$ unconformity represents a very short hiatus. When $\beta 3$ was flooded by the rising Mediterranean via the Dardanelles Strait at $\sim 12$ ky BP, marine conditions were established and algal-serpulid bioherms developed on the unconformity.

We have intimately linked the development of the younger $\Delta 1$ with the onset of water-column stratification and sapropel deposition in the Marmara and Aegean Seas (Aksu et al. 2002a; Hiscott et al. 2002). When $\Delta 2$ was actively prograding during pulse 1 (Figures 4 and 11), global sea level was still depressed and the Marmara Sea was a brackish to semi-fresh lake. As a result, the water column in the Marmara Sea remained unstratified, and no sapropel developed there. However, we predict that the contemporary Aegean Sea should have become stratified as a consequence of the low-salinity discharge through the gateway from 16-14.7 ky BP. We intend to look for organic-rich deposits of that age in the Aegean to support the proposed early history of the gateway. 
The evidence for persistent Holocene Black Sea outflow is, in our view, unambiguous. The main arguments are summarized below.

(1) Calculated sea-surface salinity in the Marmara Sea has been low since 11 ky BP, and requires a large fresh- to brackish-water input like what is provided by the Black Sea today. Local rivers cannot account for the calculated dilution of surface waters.

(2) Poor oxygenation of bottom waters in the Marmara Sea, based on the characteristics of the benthic foraminiferal communities, points to a strong and persistent Holocene pycnocline. Such intense water-column stratification can result only from the presence of a low-salinity surface layer. As before, Black Sea outflow is implicated.

(3) A climbing mid-shelf delta is present on the Marmara Sea shelf directly south of the Bosphorus exit. Local rivers cannot possibly account for its development because of their small sediment discharges. Deltaic growth is securely dated in cores from $10.5-9$ ky BP, precisely when rising global sea level was $\sim 5 \mathrm{~m}$ shallower than the elevation of the topset-foreset transition of the delta.

(4) The brackish-water outflow through the Bosphorus Strait was sufficiently strong (and initially sufficiently thin) to prevent the establishment of two-way flow in the strait until 8.5 ky BP (cf. Lane-Serff et al. 1997), so that salinization of the Black Sea was delayed and Mediterranean fauna and flora were unable to migrate northward.

(5) Even after the onset of two-way flow, the quantity of saline water which was advected northward across the Bosphorus Strait did not have an immediate impact on salinity of the shelf water masses. Hence, euryhaline molluscs did not successfully colonize the Black Sea shelves until 7.15 ky BP, well after the initial connection.

(6) The widespread and homogeneous mud drape which blankets lowstand deposits in the Marmara Sea began to accumulate at $11.5 \mathrm{ky} \mathrm{BP}$ and is uninterrupted by facies or faunal changes that would surely have accompanied a northward-flowing marine flood. Because the volume of the Marmara Sea is tiny compared with the volume of water needed to raise the level of the Black Sea from -90 $\mathrm{m}$ to $\sim-25 \mathrm{~m}$ (Figure 3A), a flood of the magnitude proposed by Ryan et al. (2003) should have left an indelible record in the Holocene succession on the shelves of the Marmara Sea. No such record exists.

More work is needed to understand fully the evolution of the Marmara Sea Gateway and Black Sea. We believe that the Outflow Hypothesis II (Figure 4) is a major step toward resolving the incompatible models of Aksu et al. (2002a) and Ryan et al. (2003). It is encouraging that new research appears to have reduced the number of disputed events. The time interval 10-7 ky BP now holds the final challenge for advocates and detractors of a catastrophic flood. 
Concerted study of cores spanning this time interval will eventually unlock the final mysteries of the Holocene paleoceanography of this exciting area.

\section{ACKNOWLEDGMENTS}

We thank the officers and crew of the RV Koca Piri Reis for invaluable assistance during a succession of successful cruises. Funding and in-kind support were provided by the Natural Sciences and Engineering Research Council of Canada, the Piri Reis Foundation, the Geological Survey of Canada, and the Vice-President (Research) of Memorial University of Newfoundland. We thank Allan Gilbert for facilitating the attendance by several members of our research team at the 2003 Columbia University conference entitled "The Black Sea Flood: Archaeological and Geological Evidence.”

\section{REFERENCES}

Abrajano, T., A.E. Aksu, R.N. Hiscott, and P.J. Mudie

2002 Aspects of carbon isotope biogeochemistry of late Quaternary sediments from the Marmara Sea and Black Sea. Marine Geology 190:151-164.

Aksu, A.E., D. Yaşar, and P.J. Mudie

1995 Paleoclimatic and paleoceanographic circumstances leading to the development of sapropel layer S1 in the Aegean Sea. Palaeogeography, Palaeoclimatology, Palaeoecology 116:71-101.

Aksu, A.E., R.N. Hiscott, and D. Yaşar

1999 Oscillating Quaternary water levels of the Marmara Sea and vigorous outflow into the Aegean Sea from the Marmara Sea-Black Sea drainage corridor. Marine Geology 153:275-302.

Aksu, A.E., T.J. Calon, R.N. Hiscott, and D. Yaşar

2000 Anatomy of the North Anatolian Fault Zone in the Marmara Sea, western Turkey: extensional basins above a continental transform. GSA Today 10(6):3-7.

Aksu, A.E., R.N. Hiscott, P.J. Mudie, A. Rochon, M.A. Kaminski, T. Abrajano, and D. Yaşar

2002a Persistent Holocene outflow from the Black Sea to the Eastern Mediterranean contradicts Noah's Flood hypothesis. GSA Today 12(5):4-10.

Aksu, A.E., R.N. Hiscott, D. Yaşar, F.I. Işler, and S. Marsh

2002b Seismic stratigraphy of Late Quaternary deposits from the southwestern Black Sea shelf: evidence for non-catastrophic variations in sea-level during the last $\sim 10000$ years. Marine Geology 190:61-94.

Aksu, A.E., R.N. Hiscott, M.A. Kaminski, P.J. Mudie, H. Gillespie, T. Abrajano, and D. Yaşar 2002c Last glacial-Holocene paleoceanography of the Black Sea and Marmara Sea: stable isotopic, foraminiferal and coccolith evidence. Marine Geology 190:119-149.

Atanassova, J., ed.

1995 Palynological data of three deep water cores from the western part of the Black Sea. In Advances in Holocene Paleoecology in Bulgaria, E. Bozilova and S. Tonkov, eds., pp. 68-83. Pensoft, Sofia.83.

Björkman, L., A. Feurdean, and B. Wohlfarth 
2003 Late-Glacial and Holocene forest dynamics at Steregoiu in the Gutaiului Mountains, Northwest Romania. Review of Palaeobotany and Palynology 124:79-111.

Bozilova, E., and H.-J. Beug

1994 Studies on the vegetation history of Lake Varna region, northern Black Sea coast of Bulgaria. Vegetation History and Archaeobotany 3:143-154.

Çağatay, M.N., N. Görür, O. Algan, C. Eastoe, A. Tchepalyga, D. Ongan, T. Kuhn, and I. Kuşcu 2000 Late Glacial-Holocene palaeoceanography of the Sea of Marmara: timing of connections with the Mediterranean and Black Seas. Marine Geology 167:191-206.

Chepalyga, A.L.(also spelled Tchepalyga)

1984 Inland sea basins. In Late Quaternary Environments of the Soviet Union, A.A. Velichko, ed., H.E. Wright, Jr., and C.W. Barnowsky, eds. English edition, pp 229-247. University of Minnesota Press, Minneapolis.

2002 Chernoe more [Black Sea]. In Dinamika landshaftnykh komponentov i vnutrennikh morskikh basseinov Severnoi Evrazii za poslednie 130000 let [Dynamics of Terrestrial Landscape Components and Inner Marine Basins of Northern Eurasia during the Last 130,000 Years], A.A. Velichko, ed., pp. 170-182. GEOS, Moscow. (In Russian)

Dolukhanov, P.M.

1997 The Pleistocene-Holocene transition in northern Eurasia: environmental changes and human adaptations. Quaternary International 41/42:181-191.

EIE

19991999 Su Yıl1 Akım Neticeleri (1999 Water Year Discharges). Elektrik Işleri Etüt Idaresi Genel Müdürlüğü.

Fairbanks, R.G.

1989 A 17,000-year glacio-eustatic sea level record: influence of glacial melting rates on the Younger Dryas event and deep-ocean circulation. Nature 342(6250):637-642.

Finch, V.C., G.T. Trewartha, A.H. Robinson, and E.H. Hammond

1957 Elements of Geography, Physical and Cultural, 4th ed. McGraw-Hill, New York.

Filipova-Marinova, M., and E. Bozilova

2002 Paleoecological conditions in the area of the prehistorical settlement in the Bay of Sozopol during the Eneolithic. Phytologia Balcanica 8:133-143.

Golubev, G.N.

1998 Environmental policy-making for sustainable development of the Caspian Sea area. In Central Eurasian Water Crisis: Caspian, Aral, and Dead Seas, I. Kobori and M.H. Glantz, eds., pp. 91-104. United Nations University Press, Tokyo.

Görür, N., M.N. Çağatay, Ö. Emre,, B. Alpar, M. Sakınç, Y. İslamoğlu, O. Algan, T. Erkal, M. Keçer, R. Akkök, and G. Karlık

2001 Is the abrupt drowning of the Black Sea shelf at 7150 yr BP a myth? Marine Geology 176:65-73.

Harrison, S.P., G. Yu, and P. Tarasov

1996 Late Quaternary lake-level record from northern Eurasia. Quaternary Research 45:138159.

Hiscott, R.N., A.E. Aksu, D. Yaşar, M.A. Kaminski, P.J. Mudie, V.E. Kostylev, J.C. MacDonald, F.I. Işler, and A.R. Lord

2002 Deltas south of the Bosphorus Strait record persistent Black Sea outflow to the Marmara Sea since 10 ka. Marine Geology 190:95-118.

Jaoshvili, S.

2002 The Rivers of the Black Sea, I. Khomerki, G. Gigineishvili, and A. Kordzadze, eds. Technical Report 71. European Environmental Agency, Copenhagen.

Johns, W.E., F. Yao, D.B. Olson, S.A. Josey, J.P. Grist, and D.A. Smeed

2003 Observations of seasonal exchange through the Straits of Hormuz and the inferred heat and freshwater budgets of the Persian Gulf. Journal Geophysical Research 108(C12): 


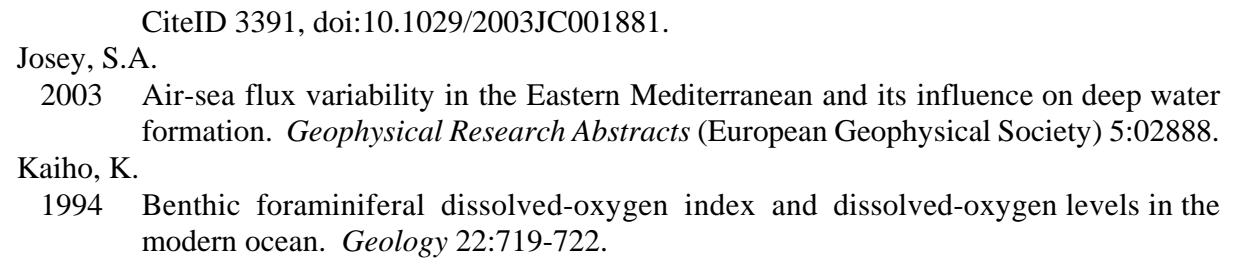

Kaminski, M.A., A.E. Aksu, M. Box, R.N. Hiscott, S. Filipescu, and M. Al-Salameen

2002 Late glacial to Holocene benthic foraminifera in the Marmara Sea: implications for Black Sea-Mediterranean Sea connections following the last deglaciation. Marine

Knox, G.A. Geology 190:165-202.

1986 Estuarine Ecosystems: A Systems Approach, Volume 1. CRC Press, Boca Raton.

Kosarev, A.N., and R.A. Makarova

1988 Ob izmeneniiakh urovnia Kaspiiskogo moria I vozmozhnosti ego prognozirovaniia [On the changes in the Caspian Sea water level and the possibility of forecasting it]. Vestnik Moskovskogo Universiteta, Seria 5, Geografija 1:21-26. (In Russian)

Lane-Serff, G., E.J. Rohling, H.L. Bryden, and H. Charnock

1997 Post glacial connection of the Black Sea to the Mediterranean and its relation to the timing of sapropel formation. Paleoceanography 12:169-174.

Major, C.O.

2002 Non-eustatic Controls on Sea Level Change in Semi-enclosed Basins. PhD thesis. Columbia University, New York.

Mamedov, A.V.

1997 The Late Pleistocene-Holocene history of the Caspian Sea. Quaternary International 41/42:161-166.

Micklin, P.P.

1988 Desiccation of the Aral Sea: A water management disaster in the Soviet Union. Science 241(4870):1170-1176.

Mudie, P.J., A. Rochon, A.E. Aksu, and H. Gillespie

2002a Dinoflagellate cysts, freshwater algae and fungal spores as salinity indicators in Late Quaternary cores from Marmara and Black seas. Marine Geology 190:203-231.

Mudie, P.J., A. Rochon, and A.E. Aksu

2002b Pollen stratigraphy of Late Quaternary cores from Marmara Sea: land-sea correlation and paleoclimatic history. Marine Geology 190:233-260.

Mudie, P.J., A. Rochon, A.E. Aksu, and H. Gillespie

2004 Late glacial, Holocene and modern dinoflagellate cyst assemblages in the AegeanMarmara-Black Sea corridor: statistical analysis and re-interpretation of the early Holocene Noah’s Flood hypothesis. Review of Palaeobotany and Palynology 128:143167.

Özsoy, E., M.A. Latif, S. Tuğrul, and Ü. Ünlüata

1995 Exchanges with the Mediterranean, fluxes, and boundary mixing processes in the Black Sea. In Mediterranean Tributary Seas, F. Briand, ed., pp. 1-25. CIESME Science Series 1. Bulletin de l'Institut Océanographique, Monaco, Special no. 15.

Polat, Ç., and S. Tuğrul

1996 Chemical exchange between the Mediterranean and Black Sea via the Turkish straits. In Dynamics of Mediterranean Straits and Channels, F. Briand, ed., pp. 167-186. CIESME Science Series 2. Bulletin de l'Institut Océanographique, Monaco, Special no. 17.

Prentice, I.C., J. Guiot, and S.P. Harrison

1992 Mediterranean vegetation, lake levels and palaeoclimate at the Last Glacial Maximum. 
Nature 360(6405):658-660.

Ryan, W.B.F., W.C. Pitman III, C.O. Major, K. Shimkus, V. Moskalenko, G.A. Jones, P. Dimitrov, N. Görür, M. Sakınç, and H. Yüce

1997 An abrupt drowning of the Black Sea shelf. Marine Geology 138:119-126.

Ryan, W.B.F., and W.C. Pitman III

1998 Noah's Flood: the New Scientific Discoveries about the Event that Changed History. Simon \& Schuster, New York.

Ryan, W.B.F.

2003 New developments from continued explorations. In The Black Sea Flood: Archaeological and Geological Evidence, program abstracts for the international conference, Columbia University, October 18-19, 2003.

Ryan, W.B.F., C.O. Major, G. Lericolais, and S.L. Goldstein

2003 Catastrophic flooding of the Black Sea. Annual Review of Earth and Planetary Sciences 31:525-554

Shackleton, N.J.

1974 Attainment of isotopic equilibrium between ocean water and the benthonic foraminifera genus Uvigerina: isotopic changes in the ocean during the last glacial. Congrès Les Méthodes Quantitatives d'Etude des Variations du Climat au Cours du Pléistocène (5-9 juin 1973). Colloque International du Centre National de la Recherche Scientifique 219:203-209.

Sofianos, S.S., W.E. Johns, and S.P. Murray

2002 Heat and freshwater budgets in the Red Sea from direct observations at Bab el Mandeb. Deep Sea Research II, 49:1323-1340.

Velichko, A.A., A.A. Andreev, and V.A. Klimanov

1997 Climate and vegetation dynamics in the tundra and forest zone during the late glacial and holocene. Quaternary International 41/42:71-96.

Yaltırak, C., M. Sakınç, A.E. Aksu, R.N. Hiscott, B. Galleb, and U.B. Ülgen

2002 Late Pleistocene uplift history along the southwestern Marmara Sea determined from raised coastal deposits and global sea-level variations. Marine Geology 190:283-305. 
